\title{
REASSESSMENT OF HYDROGEOLOGIC DATA AND REFINEMENT OF A REGIONAL GROUND-WATER-FLOW MODEL FOR THE MILFORD-SOUHEGAN GLACIAL-DRIFT AQUIFER, MILFORD, NEW HAMPSHIRE
}

\section{By Joseph R. Olimpio and Philip T. Harte}

U.S. GEOLOGICAL SURVEY

Open-File Report 95-281

(Supplement to Water-Resources Investigations Report 91-4177)

Prepared in cooperation with the

U.S. ENVIRONMENTAL PROTECTION AGENCY,

REGION I

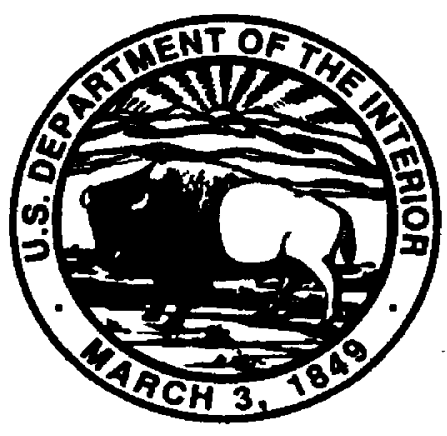

Bow, New Hampshire 


\title{
U.S. DEPARTMENT OF THE INTERIOR \\ BRUCE BABBIT, Secretary
}

\author{
U.S. GEOLOGICAL SURVEY \\ Gordon P. Eaton, Director
}

For additional information write to:

Chief, New Hampshire-Vermont District

U.S. Geological Survey

525 Clinton St.

Bow, NH 03304
Copies of this report can be purchased from:

U.S. Geological Survey Earth Science Information Center Open-Flle Report Section Denver Federal Center Box 25286, MS 517

Denver, CO 80225 


\section{CONTENTS}

Abstract

Introduction

Purpose and Scope.

Acknowledgments

Hydrogeologic-data reassessment..

Ground-water-flow patterns and stream seepage..

Saturated thickness

Hydraulic conductivity

Refinement of the ground-water-flow model .

Saturated thickness .

Horizontal hydraulic conductivity

Solution algorithm and solver

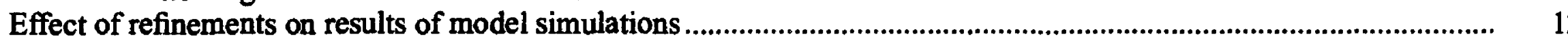

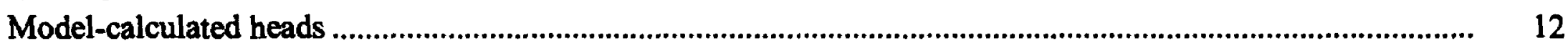

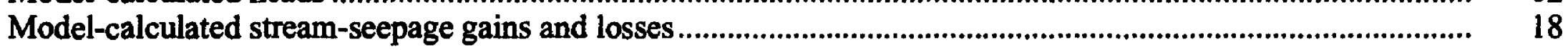

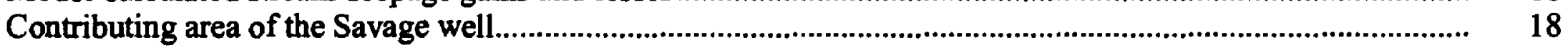

Summary ....

References cited

Appendixes

1. Water levels measured at selected wells in the Milford-Souhegan glacial-drift aquifer,

Milford, New Hampshire, 1988 and 1990

2 Stream seepage at measurement sites in the Milford-Souhegan glacial-drift aquifer,

Milford, New Hampshire, 1988 and 1990

3. Data for selected wells and boreholes in the Milford-Souhegan glacial-drift aquifer,

Milford, New Hampshire, 1990

\section{ILLUSTRATIONS}

1. Map showing location of study area, Milford, New Hampshire...

2. Map showing areal extent of the Milford-Souhegan glacial-drift aquifer and location of streams, major cultural features, and former public supply wells in Milford, New Hampshire

3a-b. Map showing losing and gaining stream reaches in the Milford-Souhegan glacial-drift aquifer and location of stream-seepage-measurement sites, Milford, New Hampshire

a. 1988

b. 1990

4a-b. Map showing location of wells in the Milford-Souhegan glacial-drift aquifer, Milford, New Hampshire

a. Wells 1-223.

b. Wells 224-341

5. Map showing revised saturated thickness of the Milford-Souhegan glacial-drift aquifer,

Milford, New Hampshire, based on geohydrologic data collected since 1990 ....

6. Map showing active and inactive cells (Ibound array) for model layer 2 of the Milford-Souhegan glacial-drift aquifer, Milford, New Hampshire

7-8. Maps showing modeled zones of hydraulic conductivity of the Milford-Souhegan glacial-drift aquifer in Milford, New Hampshire for:

7. Model layer 2 .

8. Model layer 3.

9. Map showing location of wells where measured heads were compared to model-calculated heads in the Milford-Souhegan glacial-drift aquifer, Milford, New Hampshire

10. Map showing difference between heads calculated by the previous model and the refined model, layer 3, of the Milford-Souhegan glacial-drift aquifer, Milford, New Hampshire

11. Map showing drainage basins in the Milford-Souhegan glacial-drift aquifer, Milford, New Hampshire .......

12. Map showing contributing area to the Savage well in the refined model of the Milford-Souhegan glacial-drift aquifer, Milford, New Hampshire. 


\section{TABLES}

1. Comparison of estimated horizontal hydraulic conductivities from previous well and boring data with recent estimates for the same layer and zone in the Milford-Souhegan glacial-drift aquifer, Milford, New Hampshire

2. Estimated average hydraulic conductivity and transmissivity at wells near the site of an aquifer test in the western part of the Milford-Souhegan glacial-drift aquifer, Milford, New Hampshire

3. Differences between measured and model-calculated heads in the previous and refined models for selected wells by layer in the Milford-Souhegan glacial-drift aquifer, Milford, New Hampshire

4. Differences between measured and model-calculated and stream-seepage gains and losses for each drainage basin in the Milford-Souhegan aquifer, previous and refined model, Milford, New Hampshire

\section{CONVERSION FACTORS AND VERTICAL DATUM}

\begin{tabular}{rll}
\hline Muttiply & By & To oblain \\
\hline inch (in.) & 25.4 & millimeter \\
foot $(\mathrm{ft})$ & 0.3048 & meter \\
mile $(\mathrm{mi})$ & 1.609 & kilometer \\
square $\mathrm{mile}\left(\mathrm{mi}^{2}\right)$ & 2.590 & square kilometer \\
cubic foot per second $\left(\mathrm{ft}^{3} / \mathrm{s}\right)$ & 0.02832 & cubic meter per second \\
foot per day $(\mathrm{ft} / \mathrm{d})$ & 0.3048 & meter per day \\
gallon per minute $(\mathrm{gal} / \mathrm{min})$ & 0.06308 & liter per second
\end{tabular}

Sea Level: In this report, "sea level" refers to the National Geodetic Vertical Datum of 1929- $\rightarrow$ geodetic datum derived from a general adjustment of the first-order level nets of both the United States and Canada, formerly called Sea Level Datum of 1929. 


\title{
REASSESSMENT OF GEOHYDROLOGIC DATA AND REFINEMENT OF A REGIONAL GROUND-WATER-FLOW MODEL FOR THE MILFORD-SOUHEGAN GLACIAL-DRIFT AQUIFER, MILFORD, NEW HAMPSHIRE
}

\author{
By Joseph R. Olimpio and Philip T. Harte
}

\section{ABSTRACT}

Hydrogeologic data collected since 1990 were assessed and a ground-water-flow model was refined in this study of the Milford-Souhegan glacial-drift aquifer in Milford, New Hampshire. The hydrogeologic data collected were used to refine estimates of hydraulic conductivity and saturated thickness of the aquifer, which were previously calculated during 1988-90. In October 1990 , water levels were measured at 124 wells and piezometers, and at 45 stream-seepage sites on the main stem of the Souhegan River, and on small tributary streams overlying the aquifer to improve an understanding of ground-water-flow patterns and stream-seepage gains and losses.

Refinement of the ground-water-flow model included a reduction in the number of active cells in layer 2 in the central part of the aquifer, a revision of simulated hydraulic conductivity in model layers 2 and 3 representing the aquifer, incorporation of a new block-centered finite-difference ground-water-flow model, and incorporation of a new solution algorithm and solver (a preconditioned conjugate-gradient algorithm).

Refinements to the model resulted in decreases in the difference between calculated and measured heads at 22 wells. The distribution of gains and losses of stream seepage calculated in simulation with the refined model is similar to that calculated in the previous model simulation. The contributing area to the Savage well, under average pumping conditions, decreased by 0.021 square miles from the area calculated in the previous model simulation. The small difference in the contrib- uting recharge area indicates that the additional data did not enhance model simulation and that the conceptual framework for the previous model is accurate.

\section{INTRODUCTION}

The Milford-Souhegan glacial-drift aquifer (figs. 1 and 2) was an important municipal water supply to the town of Milford, New Hampshire, until the detection (in the early 1980's) of contaminated water in two public supply wells (the Savage and Keyes wells). These wells were removed from service in 1983. After the detection of contaminated water, State and Federal agencies began hydrogeologic studies to characterize the hydrogeology and extent of contamination of the glacial-drift aquifer.

The U.S. Geological Survey (USGS), in cooperation with the U.S. Environmental Protection Agency (USEPA), studied ground-water flow to the two former public supply wells during 1988-90 utilizing a groundwater-flow model (Harte and Mack, 1992). A second cooperative study with the USEPA began in July 1990. The USGS analyzed hydrogeologic data collected since 1990 and used the data to refine the regional ground-water-flow model for the Milford-Souhegan glacial-drift aquifer. Estimates of saturated thickness and horizontal hydraulic conductivity were adjusted in the refined model. A new solution algorithm and solver were incorporated into the model to solve mathematical equations of ground-water flow. These refinements are important in keeping the ground-water-flow model current and providing the USEPA, USGS, contractors, and water managers with an updated model for evaluating options in future remediation of contamination in the western part of the glacial-drift aquifer. This report is a 


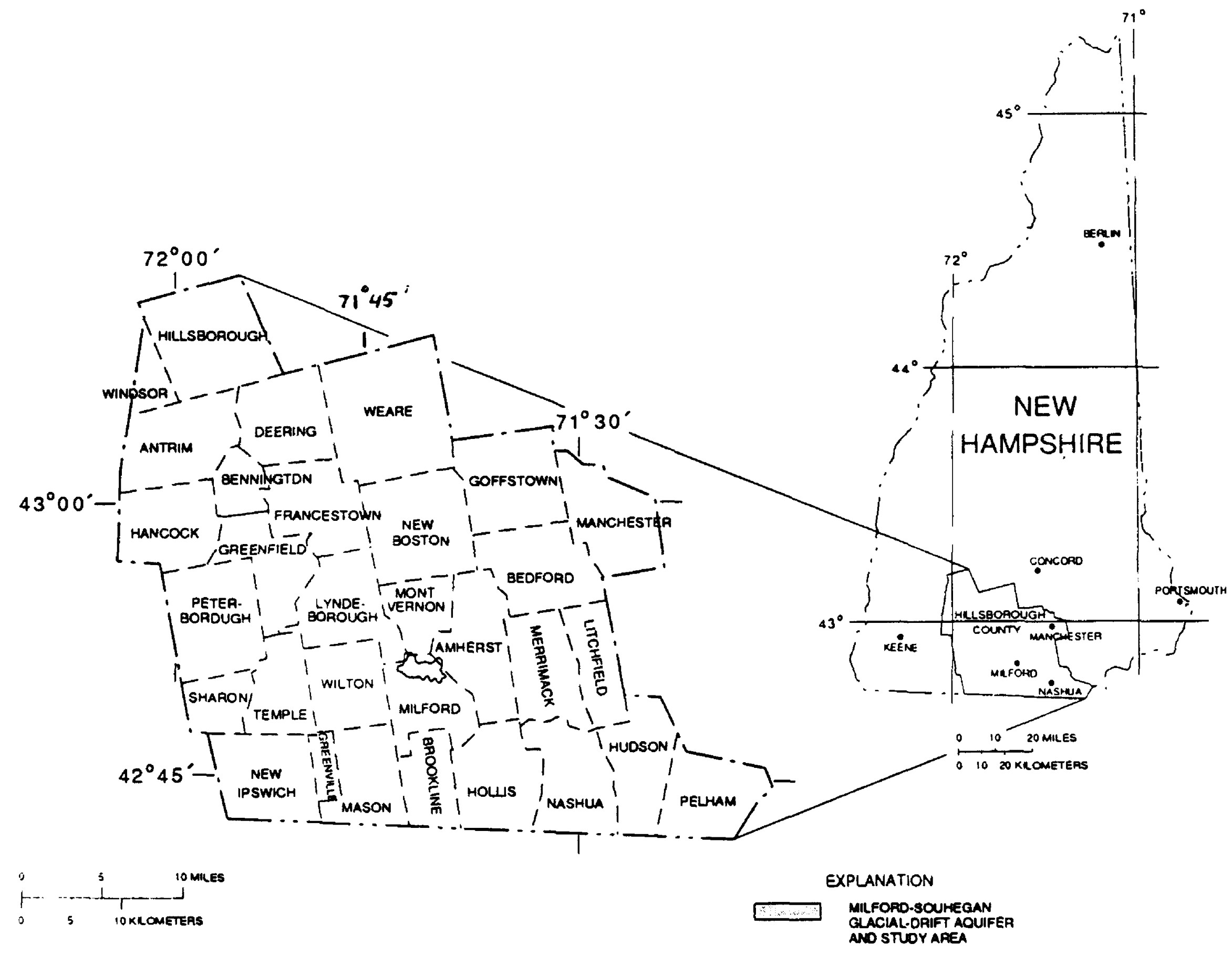

Figure 1. Location of study area, Milford, New Hampshire.

supplement to an earlier report by Harte and Mack (1992), which describes the hydrogeology of the aquifer and the simulated ground-water flow.

\section{Purpose and Scope}

This report presents a reassessment of hydrogeologic data collected during 1990-93 and describes refinements made to a regional ground-water-flow model of the Milford-Souhegan glacial-drift aquifer (Harte and Mack, 1992). Specific goals of the study were to (1) refine the previous estimates of saturated thickness and horizontal hydraulic conductivity of the aquifer utilizing hydrogeologic data collected since 1990, (2) determine gains and losses in tributary streams and the main stem of the Souhegan River, (3) compare measurements of water level and stream seepage made concurrently in October 1990 with measurements made in October 1988; (4) refine the ground-water-flow model by incorporating data collected since 1990, and (5) reassess the areal extent of the steady-state contributing area to the Savage well by use of the refined model.

\section{Acknowledgments}

Some information used in this study was provided by the New Hampshire Department of Environmental Services, Waste Management Division and Water Resources Division, and the Department of Fish and Game, Milford Fish Hatchery. Information also was provided by HMM Associates of Concord, Massachusetts. These agencies and firm are gratefully acknowledged. The authors also acknowledge officials and employees of the Town of Milford for their continued cooperation and assistance. Thanks also are extended to 


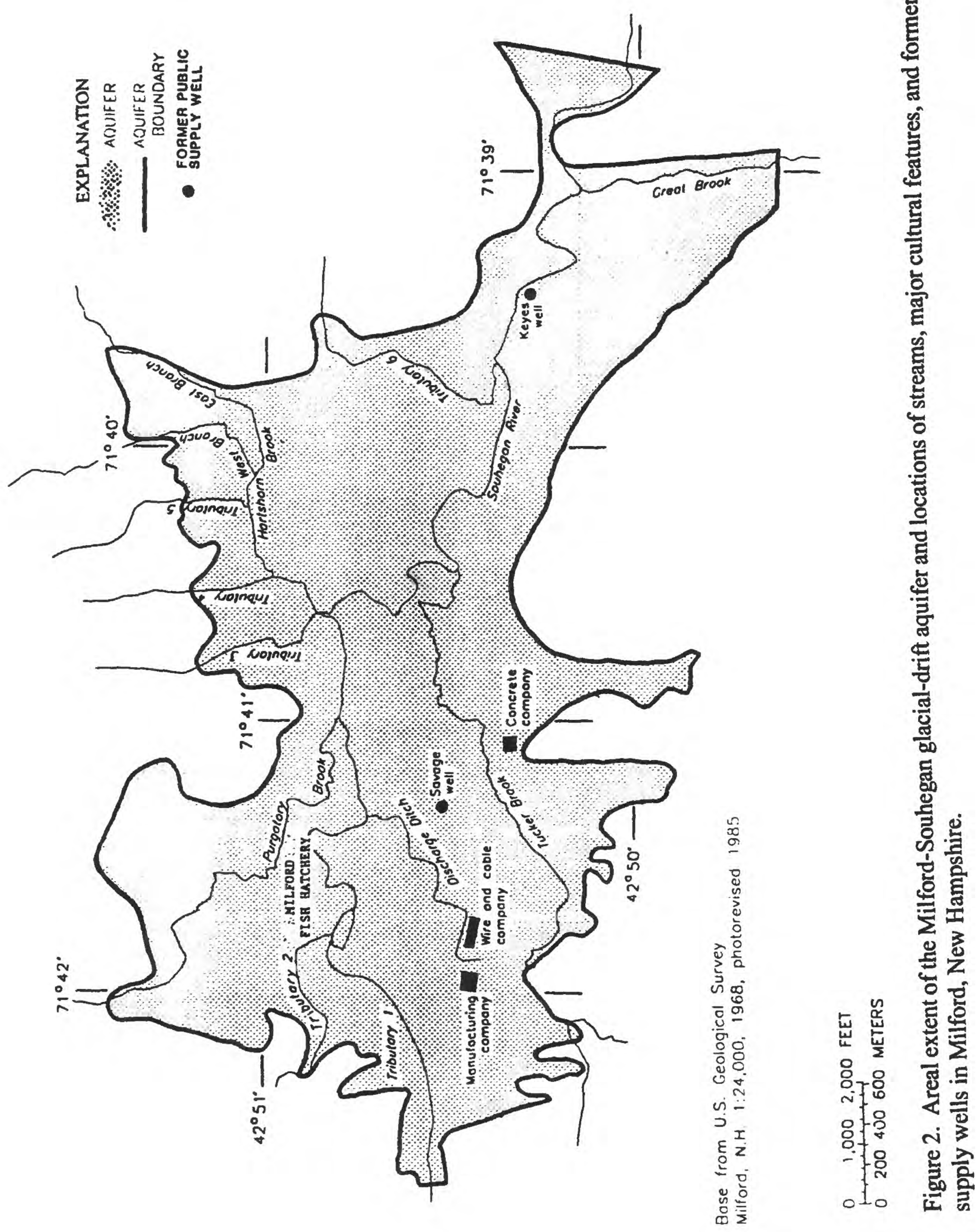


private landowners and employees of two companies in the study area who courteously assisted with data collection and provided access to their properties.

\section{HYDROGEOLOGIC-DATA REASSESSMENT}

Hydrogeologic data collected during 1990-93 were compiled from various sources, including the New Hampshire Department of Environmental Services, landowners, and companies in the study area. This data included stratigraphic logs from new wells and borings that were used to estimate saturated thickness and horizontal hydraulic conductivity of the aquifer (HMM Associates, Inc., 1991). Values of saturated thickness and hydraulic conductivity, that were used in the previous model by Harte and Mack (1992), were adjusted in areas of the aquifer where hydraulic conductivity had been poorly defined and (or) depth to till or bedrock was uncertain. Piezometers installed since 1990 provided additional information on water levels in the aquifer. Water levels also were measured in several privately owned dug wells. Water levels were measured at 124 wells and piezometers in October 1990. Stream seepage was measured at 45 sites on the main stem of the Souhegan River and on small tributary streams in the study area.

\section{Ground-Water-Flow Patterns and Stream Seepage}

The general patterns of ground-water flow in the aquifer were similar for the October 1988 and October 1990 measurement periods. Differences in groundwater levels were generally less than $1 \mathrm{ft}$ (Appendix 1) except at withdrawal wells where differences in pumping rates between the two measurement periods affected water levels.

Stream-seepage data (fig. 3 and Appendix 2) indicate that stream-seepage gains and losses are variable throughout the aquifer. Gaining and losing streamreach segments along the Souhegan River were more numerous during October 1990 than during 1988. Measurement differences result from the use of additional measurement sites, which increase the number of data points used to delineate gaining and losing reaches, and from the different hydrologic conditions that were present prior to the two measurement periods. The October 1990 measurements were made 4 days after a storm, whereas no precipitation had fallen 4 days before the October 1988 measurement. Streamflow duration was at the 60th percentile on October 22, 1990, at the Piscataquog River streamflow-gaging station near Goffstown (station number 01091500), which is 14 mi north of the study area. Streamflow duration was at the 85th percentile on October 18,1988, at the same streamflow-gaging station. Streamflow duration is defined as the percentage of time during which specified daily discharges are equaled or exceeded within a given time period.

Differences in patterns of stream-seepage gains and losses for the two periods could be the result of bank-storage effects and increased ground-water runoff during the October 1990 measurement. In order to improve an understanding of stream seepage and ground-water interaction in the glacial-drift aquifer, additional stream-seepage data, in conjunction with additional ground-water-level data, are needed to determine causes for the measured differences.

\section{Saturated Thickness}

Stratigraphic logs from new wells and borings (locations are shown in fig. 4) and field observations of geologic materials were used to refine the saturated thickness maps of the Milford-Souhegan glacial-drift aquifer (fig. 5). The recent data indicate that saturated thicknesses are shallower adjacent to the Souhegan River in the central part of the aquifer and near the Milford Public Fish Hatchery in the northwestern part of the aquifer than the saturated thicknesses reported by Harte and Mack (1992). Data for selected wells and borings (1990-93) in the Milford-Souhegan glacial-drift aquifer are listed in Appendix 3.

\section{Hydraulic Conductivity}

Horizontal hydraulic conductivities estimated from stratigraphic logs of wells and borings generally are similar to the estimates of hydraulic conductivity made in the previous investigation (Harte and Mack, 1992). This similarity supports the original conceptual representation of horizontal hydraulic conductivity delineated by model layer and zone. Horizontal hydraulic conductivity was delineated into zones based on the layer and zone configuration used by Harte and Mack (1992, figs. 14-19). Similar values were grouped into zones of equal hydraulic conductivity. Zonal hydraulic conductivities for each layer were determined by averaging horizontal hydraulic conductivities computed from stratigraphic logs of test holes that penetrate the 


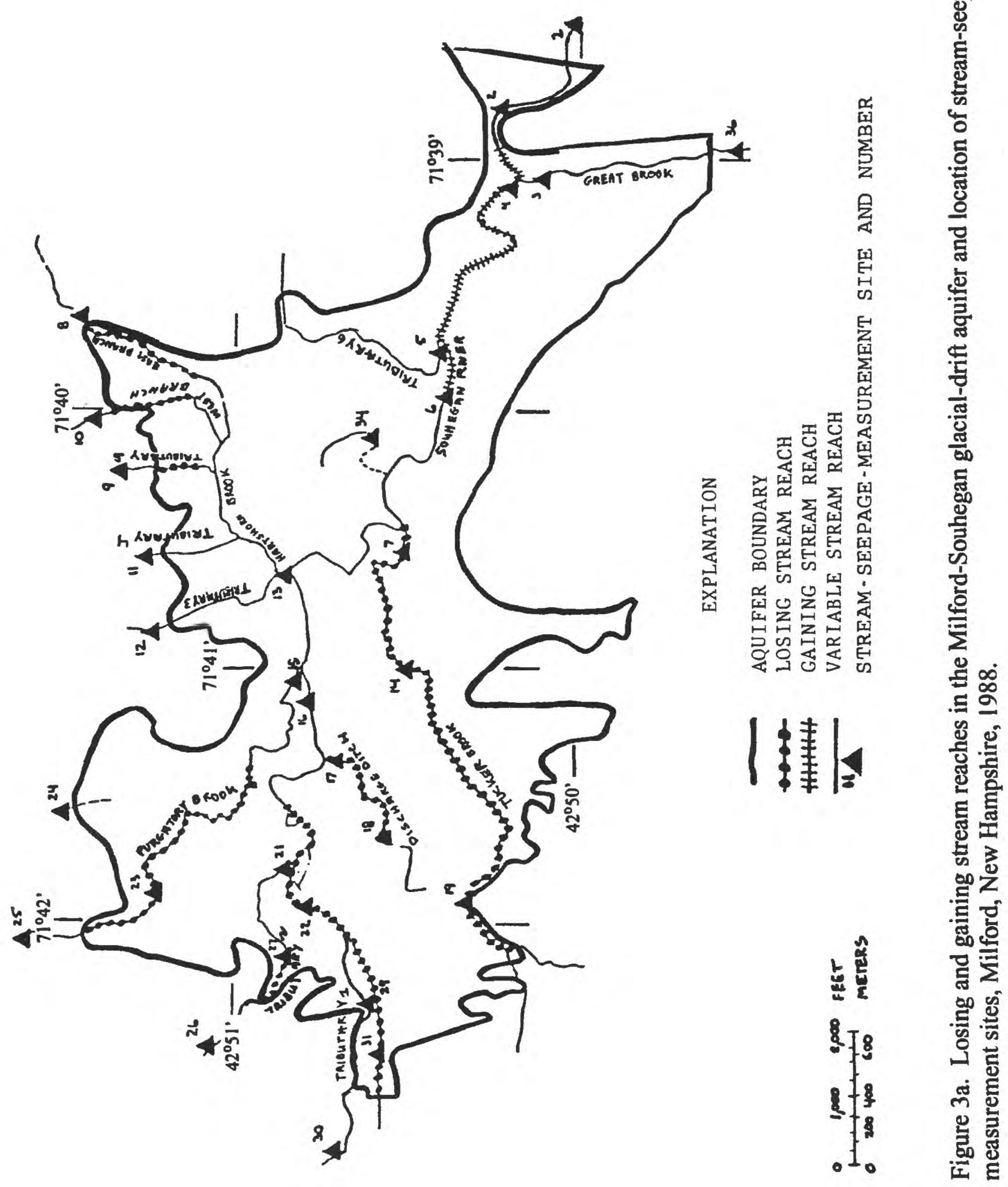




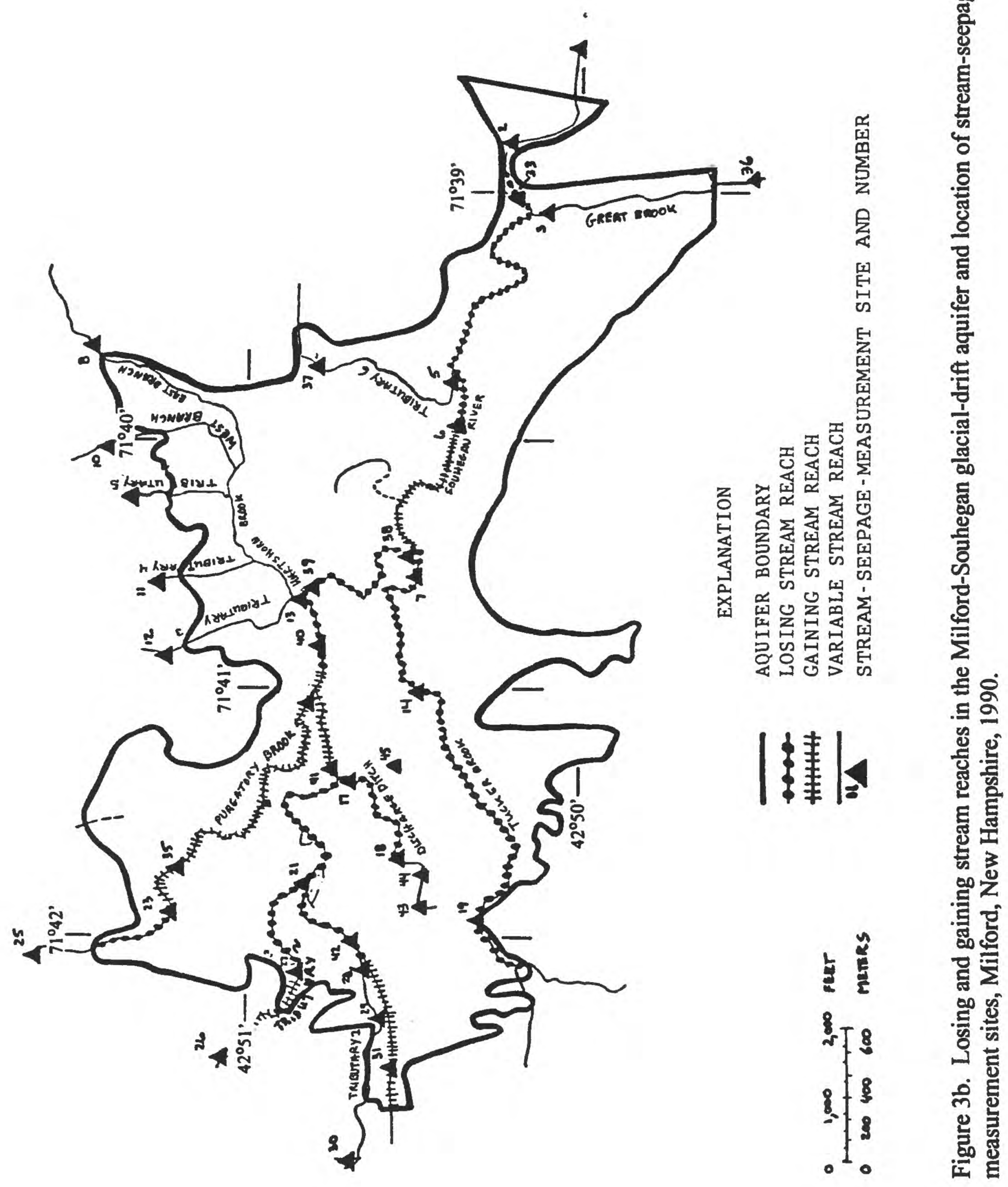




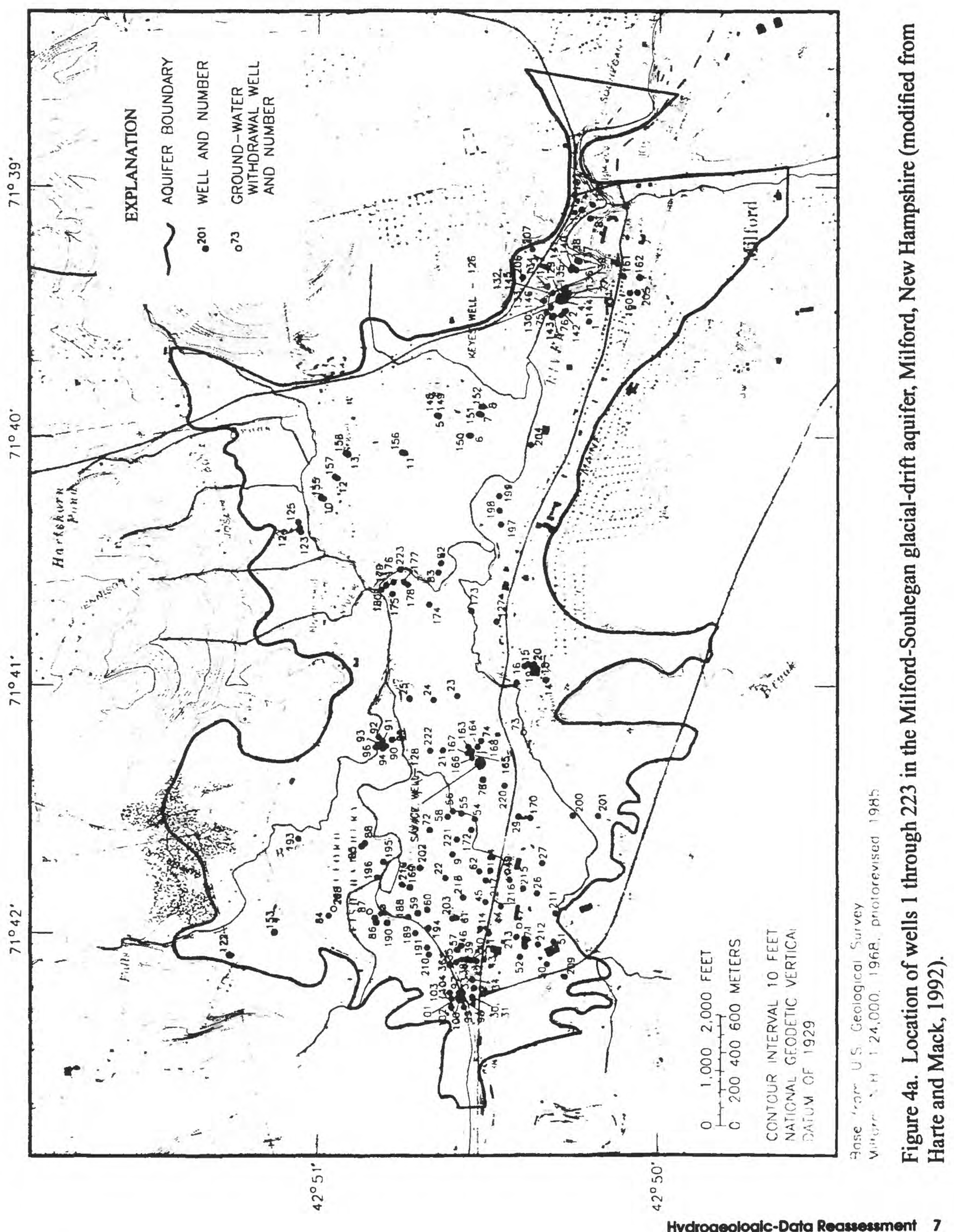




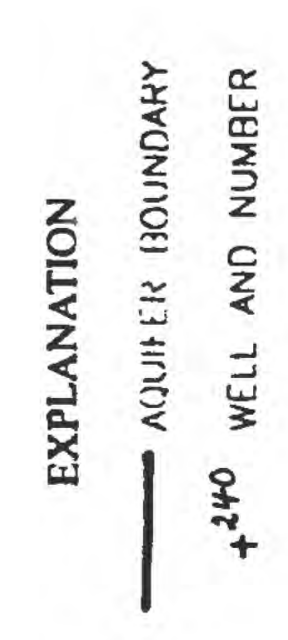




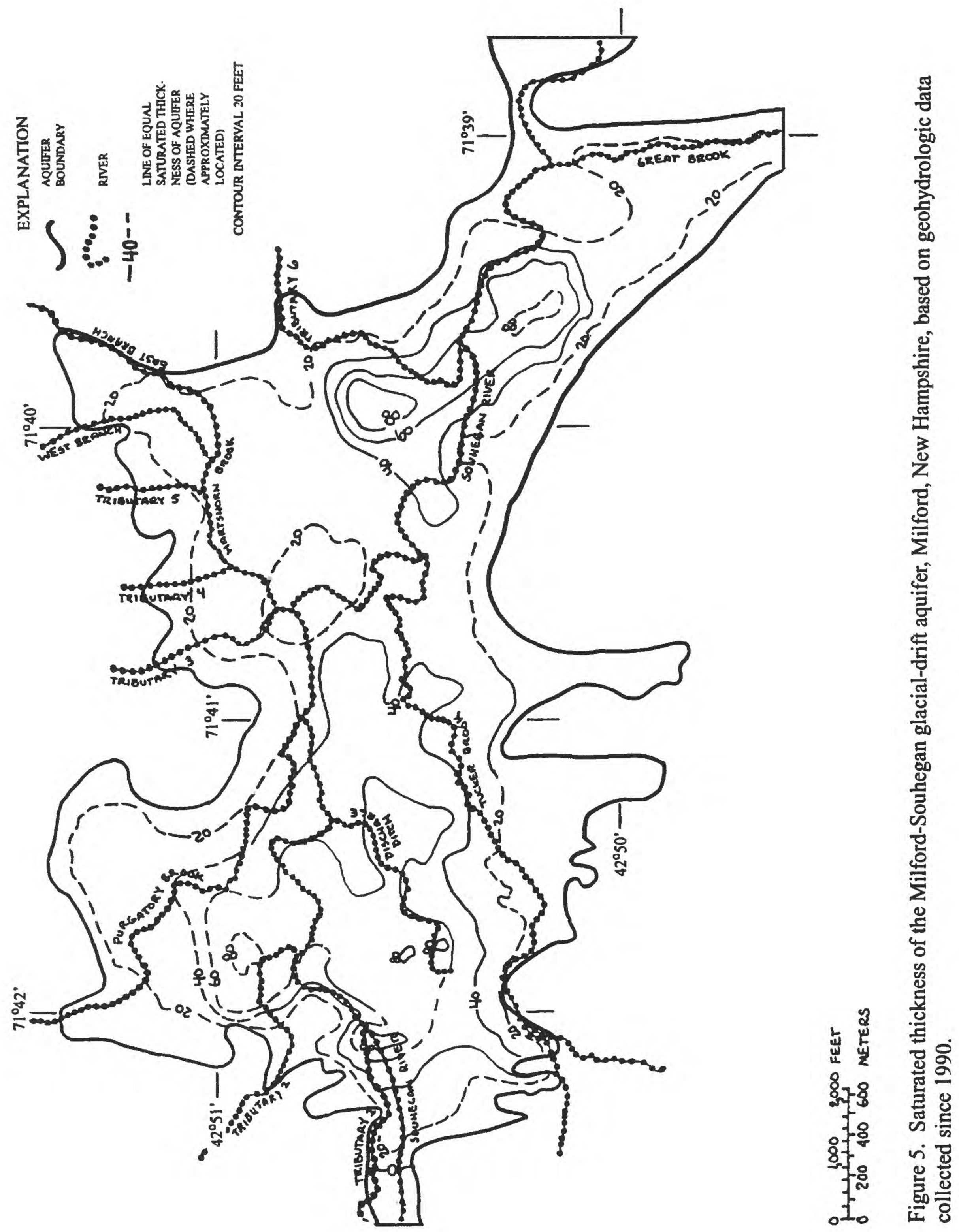


layer, utilizing methods described by Harte and Mack (1992, p. 30-38). A comparison of estimated horizontal hydraulic conductivity values collected from previously installed wells and borings (pre 1990) with recently estimated values (1990-93) for the same layer and zone is shown in table 1 . The average values reported in table 1 represent an integration of horizontal hydraulic conductivity estimates from all well logs penetrating a zone.

Estimated horizontal hydraulic conductivity and transmissivity at wells near an aquifer test conducted and analyzed by a private consultant (HMM Associates, Inc., 1989) are higher than estimates used in this investigation. The higher estimated horizontal hydraulic conductivities are representative of material found over a larger aquifer area than over an area near a well in which lithologic data were available (table 2 ). The variation in estimates of horizontal hydraulic conductivity from the aquifer test indicates a greater variability within model zones than the variability from lithologic logs.

Data were not available on vertical hydraulic conductivity; therefore, ratios of horizontal to vertical hydraulic conductivity ranging from 1:10 between layers 1 and 2, to $1: 100$ between layers 2,3,4, and 5 were assumed, as described by Harte and Mack (1992).

\section{REFINEMENT OF THE GROUND-WATER-FLOW MODEL}

A block-centered, finite-difference ground-waterflow model, known as Modflow (McDonald and Harbaugh, 1988) was used to simulate steady-state ground-water flow in three dimensions in the MilfordSouhegan glacial-drift aquifer. The model grid consists of 76 rows and 122 columns. Horizontal dimensions represented by grid cells range from 50 to $200 \mathrm{ft}$ along rows and columns. The model is vertically discretized into a maximum of five layers, each about $20 \mathrm{ft}$ thick. (For a complete description of the model construction, see Harte and Mack, 1992.) Refinements to the groundwater-flow model included changes in saturated thickness and distribution of horizontal hydraulic conductivity, and the incorporation of a new solution algorithm designed for MODFLOW (McDonald and others, 1991).

\section{Saturated Thickness}

The bottom altitude of model layers was increased adjacent to the Souhegan River in the central part of the aquifer, which reduced the area of active cells for model layer 2 (fig. 6). This change was made because field observations of till and bedrock indicated that the saturated thickness was shallower than the saturated thickness previously reported by Harte and Mack (1992).

\section{Horizontal Hydraullc Conductivity}

Horizontal hydraulic conductivities were modified for model layers 2 and 3. The revised zonation is shown in figures 7 and 8 . In each zone, horizontal hydraulic conductivity is homogeneous and isotropic (Harte and Mack, 1992). Hydraulic conductivities assigned to layer 2 of the model are divided into five zones, as in the previous model. Assigned hydraulic-conductivity values were decreased slightly in zones 1 , and 2 and increased in zones 3,4, and 5 . In layer 3 , the number of horizontal hydraulic conductivity zones was increased from four in the previous model to five in the refined model. The hydraulic conductivity of this layer ranges from $1 \mathrm{ft} / \mathrm{d}$ in zone 1 to $260 \mathrm{ft} / \mathrm{d}$ in zone 5 (fig. 8 ).

\section{Solution Algorithm and Solver}

A solution algorithm that allows cells that go dry during the model simulation to resaturate (McDonald and others, 1991) was used in the revised model. The solution algorithm allowed for a precise solution of the finite-difference equations used for areas near withdrawal wells that had gone dry during simulation with the previous model (Harte and Mack, 1992). Previously, a cell that could not resaturate was removed from the active area of the model. Cells tended to go dry near withdrawal wells because of desaturation of the simulated aquifer near the withdrawal well. The new solution algorithm provides a more accurate solution than that used in the previous model because dry cells are resaturated and not removed from the model simulation.

A preconditioned, conjugate-gradient solution solver developed by Hill (1990) was utilized to solve the finite-difference equations for hydraulic head. This technique was preferred over other solvers because numerically difficult problems are solved more easily. 
Table 1. Comparison of estimated horizontal hydraulic conductivities from previous weil and boring data with recent estimates for the same layer and zone in the Miliford-Souhegan giacial-drift aquifer, Milford, New Hampshire

[Layers 2 and 3 are shown in figures 7 and 8; layers 1, 4, and 5 are shown in figures 15, 18, and 19 (Harte and Mack, 1992); ft/d, foot per day; previous data: pre 1990 (Harte and Mack, 1992); recent data: 1990-93, present investigation]

\begin{tabular}{|c|c|c|c|c|c|c|}
\hline \multirow{3}{*}{ Layer } & \multirow{3}{*}{ Zone } & \multicolumn{4}{|c|}{ Horizontal hydraulic conductivity } & \multirow{3}{*}{$\begin{array}{l}\text { Difference } \\
\text { in zonal value between } \\
\text { previous and recent data }\end{array}$} \\
\hline & & \multicolumn{2}{|c|}{ Previous data (pre 1990) } & \multicolumn{2}{|c|}{ Recent data (1990-93) } & \\
\hline & & $\begin{array}{c}\text { Average }^{1} \\
\text { (ft/d) }\end{array}$ & $\begin{array}{l}\text { Model value } \\
\text { (ft/d) }\end{array}$ & $\begin{array}{c}\text { Average }^{1} \\
\text { (ft/d) }\end{array}$ & $\begin{array}{c}\text { Model value } \\
\text { (ft/d) }\end{array}$ & \\
\hline 1 & 4 & 182.5 & 170 & 178.6 & 170 & 0 \\
\hline 1 & 5 & 197.5 & 190 & 187.9 & 190 & 0 \\
\hline 2 & 2 & 52.5 & 60 & 59.5 & 58 & -2 \\
\hline 2 & 3 & 103.0 & 110 & 110.8 & 95 & -15 \\
\hline 2 & 4 & 119.5 & 125 & 122.4 & 157 & +32 \\
\hline 2 & 5 & 207.5 & 210 & 204.1 & 229 & +19 \\
\hline 3 & 2 & 40.9 & 55 & 41.2 & 38 & -17 \\
\hline 3 & 3 & 140.4 & 135 & 142.6 & 55 & -80 \\
\hline 3 & 4 & 216.2 & 200 & 210.1 & 260 & +60 \\
\hline 4 & 5 & 151.8 & 150 & 122.7 & 150 & 0 \\
\hline 5 & 1 & 52.3 & 50 & 50.0 & 50 & 0 \\
\hline
\end{tabular}

${ }^{1}$ Average value estimated from wells in the zone.

Table 2. Estimated average hydraulic conductivity and transmissivity at wells near the site of an aquifer test in the western part of the Milford-Souhegan giacial-drift aquifer, Milford, New Hampshire

[No., number; $\mathrm{ft}$, foot; $\mathrm{ft} / \mathrm{d}$, foot per day; $\mathrm{ft}^{2} / \mathrm{d}$, foot squared per day]

\begin{tabular}{|c|c|c|c|c|c|c|c|}
\hline \multirow[b]{2}{*}{$\begin{array}{l}\text { Well No. } \\
\text { (fig.4) }\end{array}$} & \multirow[b]{2}{*}{$\begin{array}{c}\text { Saturated } \\
\text { thickness } \\
\text { (ft) }\end{array}$} & \multicolumn{3}{|c|}{ Horizontal hydraulic conductivity } & \multicolumn{3}{|c|}{ Transmissivity } \\
\hline & & $\begin{array}{c}\text { Aquifer } \\
\text { test } \\
\text { (ft/d) }\end{array}$ & $\begin{array}{c}\text { Lithologic } \\
\log \\
\text { (ft/d) }\end{array}$ & $\begin{array}{l}\text { Model } \\
\text { value } \\
\text { assigned } 1 \\
(\mathrm{ft} / \mathrm{d})\end{array}$ & $\begin{array}{c}\begin{array}{c}\text { Aquifer } \\
\text { test } \\
\left(\mathrm{ft}^{2} / \mathrm{d}\right)\end{array}\end{array}$ & $\begin{array}{l}\text { Lithologic } \\
\qquad \log \\
\left(\mathrm{ft}^{2} / \mathrm{d}\right)\end{array}$ & $\begin{array}{l}\text { Model } \\
\text { value } \\
\text { assigned } \\
\left(\mathrm{ft}^{2} / \mathrm{d}\right)\end{array}$ \\
\hline 47 & 64 & 53 & 117 & 95 & 3,392 & 7,488 & 11,150 \\
\hline 313 & 51 & 218 & 199 & 108 & 11,118 & 10,149 & 8,550 \\
\hline 213 & 51 & 254 & 199 & 108 & 12,954 & 10,149 & 8,550 \\
\hline 325 & 71 & 200 & 138 & 114 & 14,200 & 9,798 & 11,700 \\
\hline 171 & 52 & 307 & 137 & 107 & 15,964 & 7,124 & 7,595 \\
\hline 44 & 72 & 241 & 164 & 114 & 17,352 & 11,808 & 11,900 \\
\hline 45 & 90 & 98 & 76 & 122 & 8,820 & 6,840 & 14,600 \\
\hline 215 & 55 & 241 & 146 & 134 & 13,255 & 8,030 & 8,050 \\
\hline 321 & 77 & 187 & 119 & 139 & 14,399 & 9,163 & 14,170 \\
\hline
\end{tabular}

\footnotetext{
${ }^{1}$ Assigned value is an average over the well-depth interval.
} 


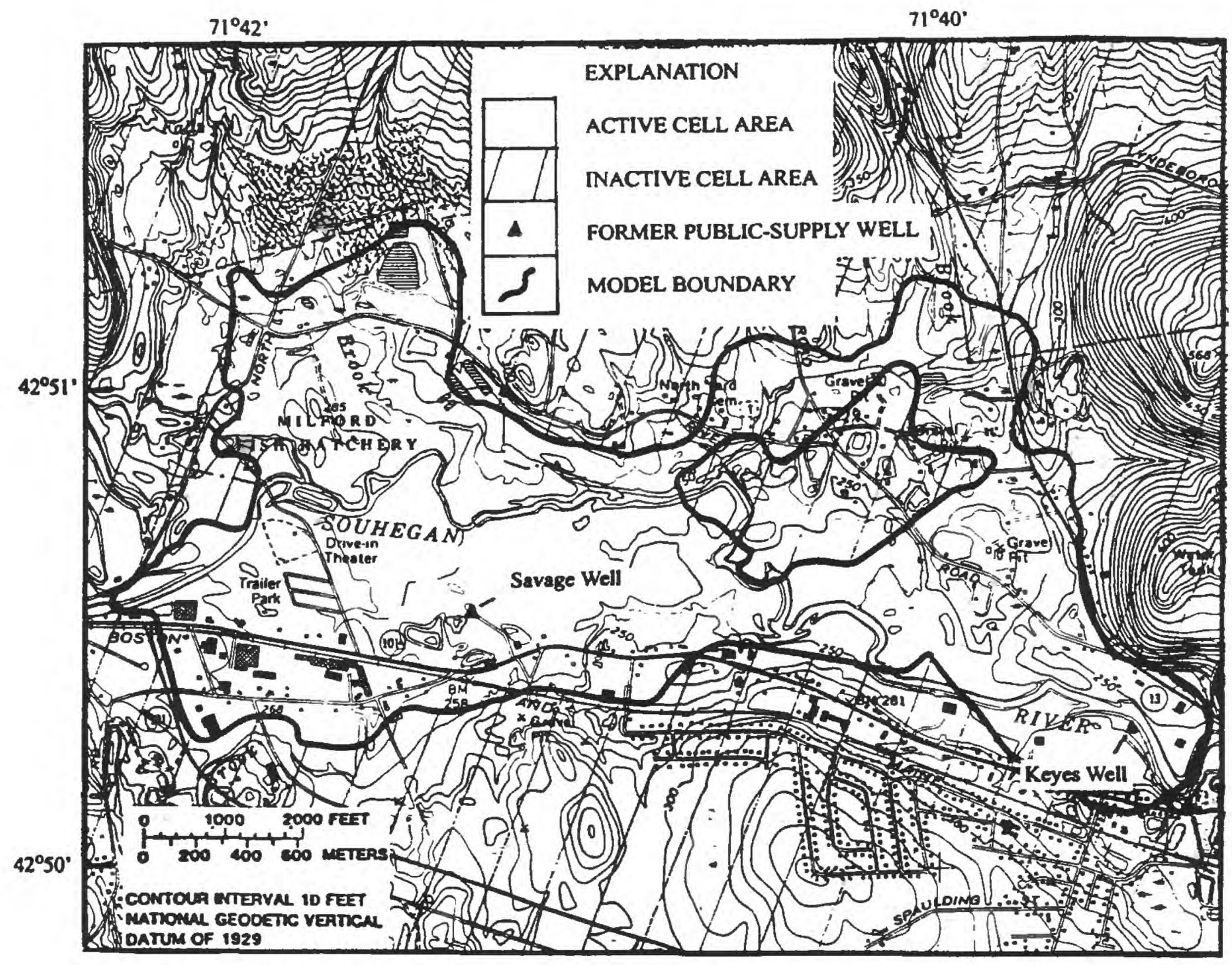

Figure 6. Active and inactive cell areas for model layer 2 of the Milford-Souhegan glacial-drift aquifer, Milford, New Hampshire.

\section{EFFECTS OF REFINEMENTS ON RESULTS OF MODEL SIMULATION}

The effects of model refinements were evaluated by comparing model-calculated heads with heads measured in October 1988. This is the same data set used to evaluate the previous model. Effects of model results on stream-seepage gains and losses and the contributing area to the Savage well also were evaluated.

\section{Model-Calculated Heads}

Refinement of the distribution of horizontal hydraulic conductivity resulted in observable differences in model-calculated heads. The refinements improved the match between model-calculated and measured heads (table 3), especially in the southwestern part of the aquifer where most modifications were made. The locations of measured heads are shown in figure 9.

Differences in heads calculated in simulation with the previous model (Harte and Mack, 1992) and then calculated by the refined model (fig. 10) are small except near withdrawal well 208 at the Milford Public Fish Hatchery. Because of large pumping rates at this well, the model is sensitive to small changes in hydraulic conductivity. A similar difference in hydraulic conductivity at withdrawal well 47 is the result of a change in well location from what was used in the previous model. At the remaining withdrawal wells, changes in model-input data resulted in small but improved head matches. 


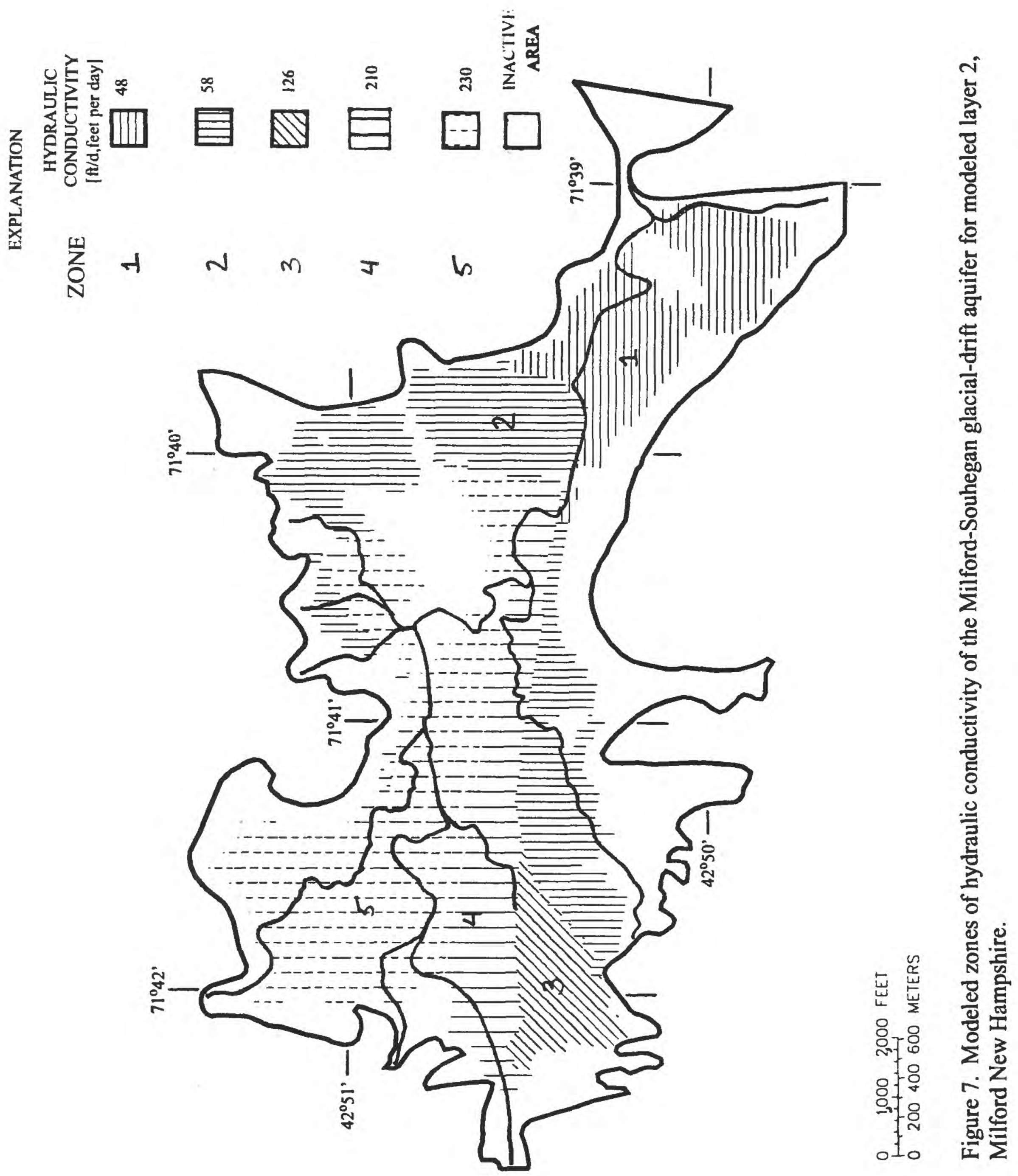




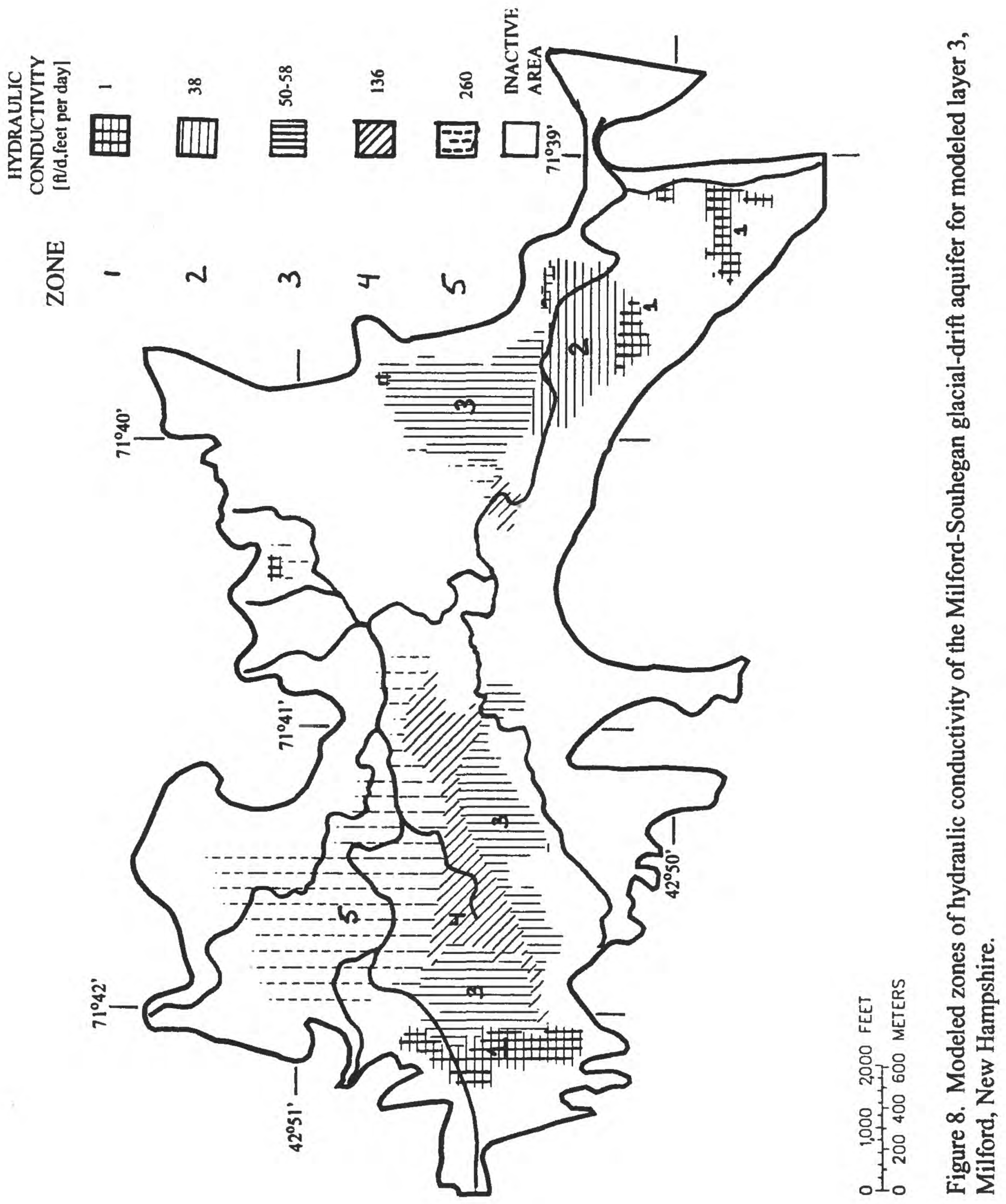




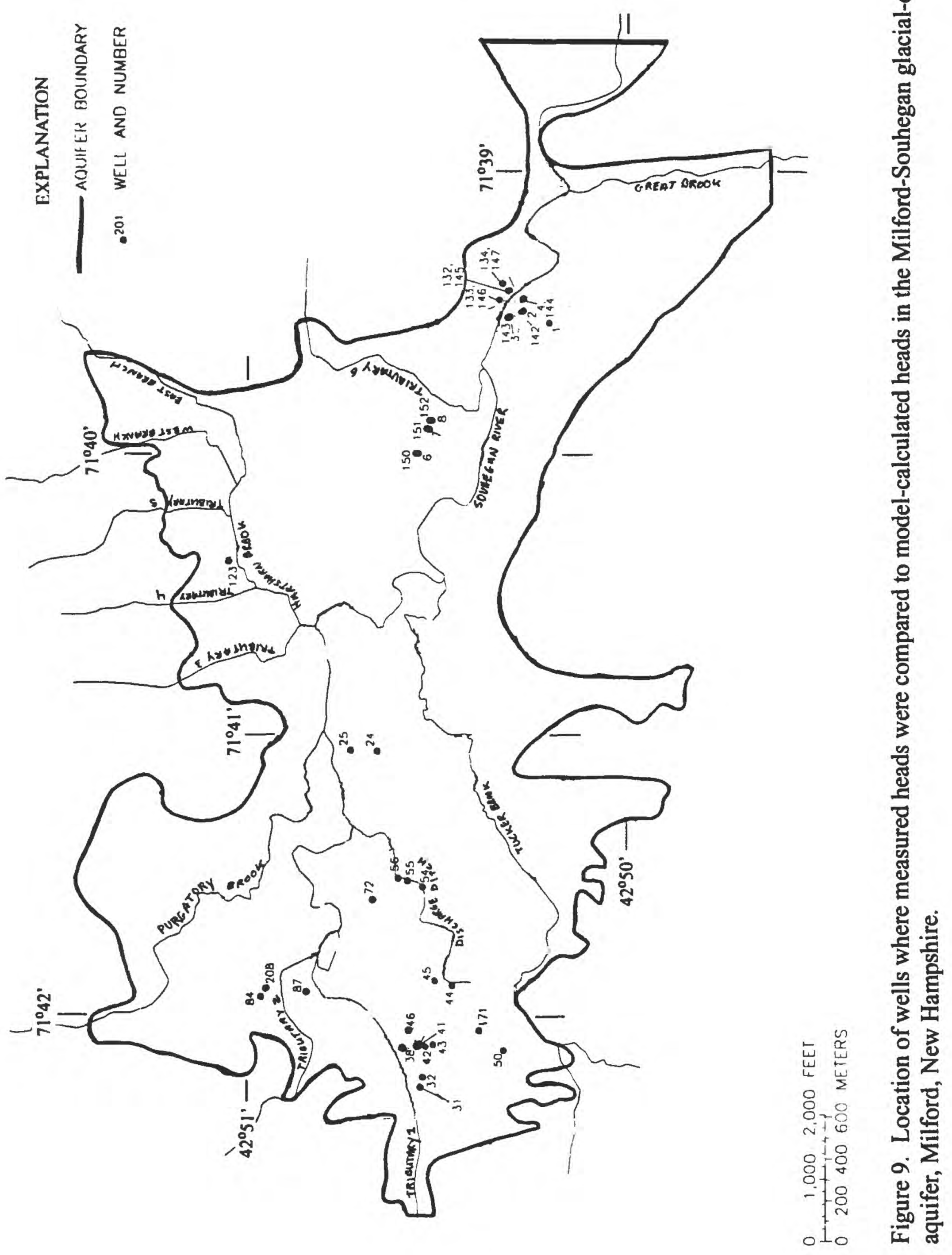


Table 3. Differences between measured and model-caiculated heads in the previous and refined models for selected wells by layer in the Mllford-Souhegan glacial-drift aquifer, Mllford, New Hampshire

[No., number; head values are in feet; -, negative difference]

\begin{tabular}{|c|c|c|c|c|c|c|c|}
\hline \multirow{2}{*}{$\begin{array}{c}\text { Well } \\
\text { No. } \\
\text { (See fig. 4) }\end{array}$} & \multicolumn{2}{|c|}{ Model node } & \multirow{2}{*}{$\begin{array}{c}\text { Measured } \\
\text { head } \\
\text { October } \\
1988\end{array}$} & \multicolumn{2}{|c|}{ Previous model } & \multicolumn{2}{|c|}{ Refined model } \\
\hline & Row & Column & & $\begin{array}{l}\text { Model- } \\
\text { calculated } \\
\text { head }\end{array}$ & $\begin{array}{c}\text { Difference } \\
\text { between } \\
\text { model- } \\
\text { calculated } \\
\text { head and } \\
\text { measured } \\
\text { head }\end{array}$ & $\begin{array}{l}\text { Model- } \\
\text { calculated } \\
\text { head }\end{array}$ & $\begin{array}{c}\text { Difference } \\
\text { between model- } \\
\text { caiculated } \\
\text { head and } \\
\text { measured head }\end{array}$ \\
\hline
\end{tabular}

\begin{tabular}{|c|c|c|c|c|c|c|c|}
\hline \multicolumn{8}{|c|}{ Model Layer 1} \\
\hline 31 & 56 & 8 & 264.95 & 262.47 & -2.48 & 262.43 & -2.52 \\
\hline 32 & 56 & 8 & 264.47 & 262.47 & -2.00 & 262.43 & -2.04 \\
\hline 37 & 48 & 10 & 260.39 & 260.36 & -.03 & 260.51 & .12 \\
\hline 38 & 50 & 11 & 259.86 & 259.51 & -.35 & 259.68 & .18 \\
\hline 41 & 53 & 11 & 259.84 & 259.48 & -.36 & 259.64 & .20 \\
\hline 42 & 55 & 11 & 259.98 & 259.48 & -.50 & 259.59 & -.39 \\
\hline 50 & 70 & 12 & 262.55 & 260.54 & -2.01 & 259.97 & -2.58 \\
\hline 54 & 46 & 24 & 253.80 & 254.90 & 1.10 & 254.61 & .81 \\
\hline 55 & 41 & 24 & 253.54 & 254.42 & .88 & 254.15 & .61 \\
\hline 56 & 38 & 24 & 252.99 & 254.12 & 1.13 & 253.83 & .84 \\
\hline 72 & 32 & 22 & 254.34 & 253.82 & -.52 & 253.51 & -.83 \\
\hline 123 & 16 & 70 & 251.24 & 251.76 & .52 & 251.59 & .35 \\
\hline 142 & 48 & 97 & 235.90 & 236.02 & .12 & 236.01 & .11 \\
\hline 143 & 44 & 94 & 235.52 & 235.82 & .30 & 235.81 & .29 \\
\hline 144 & 46 & 101 & 235.58 & 235.27 & -.31 & 235.26 & .32 \\
\hline 145 & 42 & 102 & 235.69 & 234.87 & -.82 & 234.86 & .83 \\
\hline 146 & 40 & 100 & 235.69 & 235.01 & -.68 & 235.00 & -.69 \\
\hline 147 & 40 & 105 & 236.01 & 235.12 & -.89 & 235.11 & -.90 \\
\hline 150 & 29 & 81 & 238.15 & 242.51 & 4.36 & 242.20 & 4.05 \\
\hline 151 & 30 & 83 & 237.24 & 241.49 & 4.25 & 241.27 & 4.03 \\
\hline 152 & 30 & 83 & 238.74 & 241.49 & 2.75 & 241.27 & 2.53 \\
\hline
\end{tabular}


Table 3. Differences between measured and modei-calculated heads in the previous and refined models for selected wells by layer in the Milford-Souhegan glacial-drift aqulfer, Milford, New Hampshire--Continued

\begin{tabular}{|c|c|c|c|c|c|c|c|}
\hline \multirow{2}{*}{$\begin{array}{c}\text { Well } \\
\text { No. } \\
\text { (See fig. 4) }\end{array}$} & \multicolumn{2}{|c|}{ Model node } & \multirow{2}{*}{$\begin{array}{c}\text { Measured } \\
\text { head } \\
\text { October } \\
1988\end{array}$} & \multicolumn{2}{|c|}{ Previous model } & \multicolumn{2}{|c|}{ Refined model } \\
\hline & Row & Column & & $\begin{array}{l}\text { Model- } \\
\text { calculated } \\
\text { head }\end{array}$ & $\begin{array}{c}\text { Difference } \\
\text { between } \\
\text { model- } \\
\text { calculated } \\
\text { head and } \\
\text { measured } \\
\text { head }\end{array}$ & $\begin{array}{l}\text { Model- } \\
\text { calculated } \\
\text { head }\end{array}$ & $\begin{array}{l}\text { Difference } \\
\text { between model- } \\
\text { calcuiated } \\
\text { head and } \\
\text { measured head }\end{array}$ \\
\hline
\end{tabular}

Model Layer 2

$\begin{array}{rrrrrrrr}43 & 58 & 11 & 260.56 & 259.46 & -1.10 & 259.47 & -1.09 \\ 44 & 61 & 16 & 256.85 & 257.68 & .83 & 257.47 & -.62 \\ 45 & 55 & 16 & 256.22 & 257.45 & 1.23 & 257.23 & 1.01 \\ 171 & 68 & 13 & 259.99 & 258.44 & -1.55 & 257.95 & -2.04\end{array}$

Model Layer 3

$\begin{array}{rrrrrrrr}1 & 57 & 95 & 237.26 & 237.22 & -0.04 & 237.17 & -0.09 \\ 2 & 48 & 97 & 235.79 & 236.02 & .23 & 236.01 & .22 \\ 3 & 44 & 95 & 235.59 & 235.75 & .16 & 235.75 & .16 \\ 4 & 46 & 102 & 235.61 & 235.37 & -.24 & 235.37 & -.24 \\ 6 & 29 & 81 & 238.13 & 242.53 & 4.40 & 242.22 & 4.09 \\ & & & & & & & \\ 7 & 30 & 83 & 237.30 & 241.50 & 4.20 & 241.29 & 3.99 \\ 8 & 30 & 83 & 237.13 & 241.50 & 4.37 & 241.29 & 4.16 \\ 24 & 30 & 57 & 247.56 & 249.44 & 1.88 & 249.37 & 1.81 \\ 25 & 28 & 57 & 243.59 & 248.96 & 5.37 & 248.91 & 5.32 \\ 84 & 25 & 14 & 235.20 & 243.13 & 7.93 & 248.57 & 13.37 \\ & & & & & & & \\ 87 & 28 & 14 & 241.65 & 237.07 & -4.58 & 1243.87 & 2.22 \\ 132 & 42 & 102 & 235.65 & 235.20 & -.45 & 235.20 & -.45 \\ 133 & 40 & 99 & 235.72 & 235.27 & -.45 & 235.27 & -.56 \\ 134 & 40 & 104 & 235.97 & 235.17 & -.80 & 235.16 & -.81 \\ 208 & 25 & 14 & 224.60 & 1236.71 & - & 1227.80 & 8.68\end{array}$

Model Layer 4

46

49

12

$259.16 \quad 258.57$

$-.59$

258.36 $-.80$

${ }^{1}$ Simulated head was adjusted to represent head at a pumped well utilizing the method described by Trescott and other $(1976$, p. 9). 


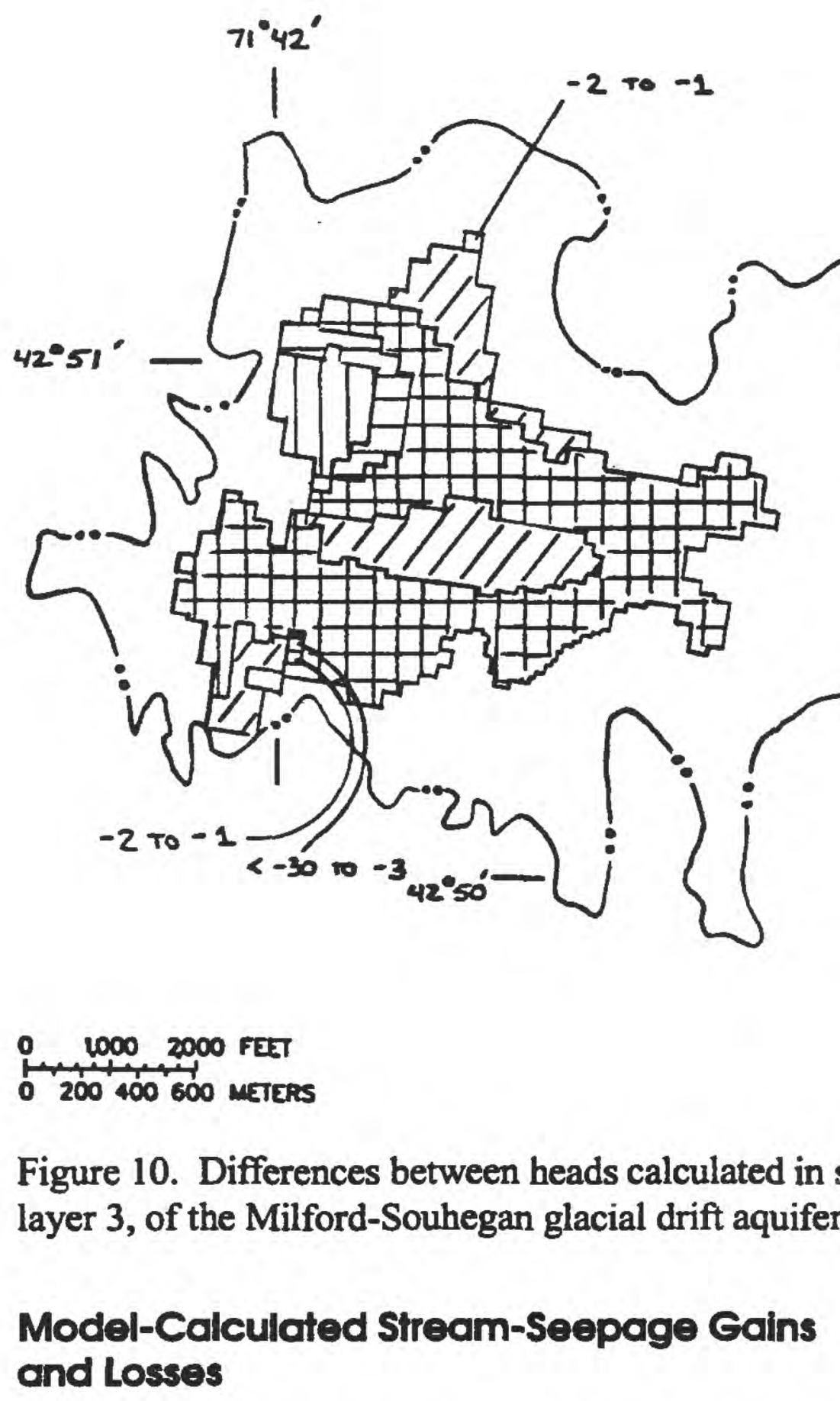

Results of stream seepage calculated in the refined model compare favorably with those calculated in the previous model (table 4) for the drainage basins shown in figure 11. Stream seepage calculated in the previous and refined models were compared to the October 1988 field stream-seepage measurements. As in the previous model, stream seepages calculated in the refined model generally indicate patterns of losing and gaining stream reaches similar to those measured in 1988. Differences between calculated and measured stream seepages are less in drainage basins $2,3,5,6$ and 9 in the refined model than in the same drainage basins in the previous model (table 4 and fig. 11).

\section{Contributing Area of the Savage Well}

The $0.127-\mathrm{mi}^{2}$ contributing area of the Savage well covers an area between an industrial discharge ditch,
EXPLANATION

BOUNDARY OF AQUIFER

DIFFERENCE BETWEEN

MODEL-CALCULATED

HEADS, IN FEET

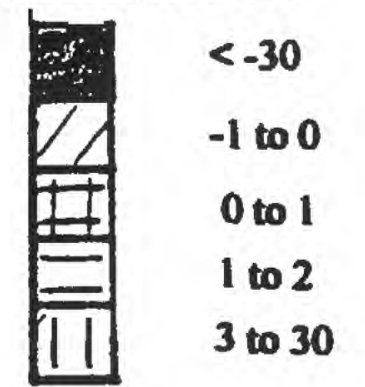




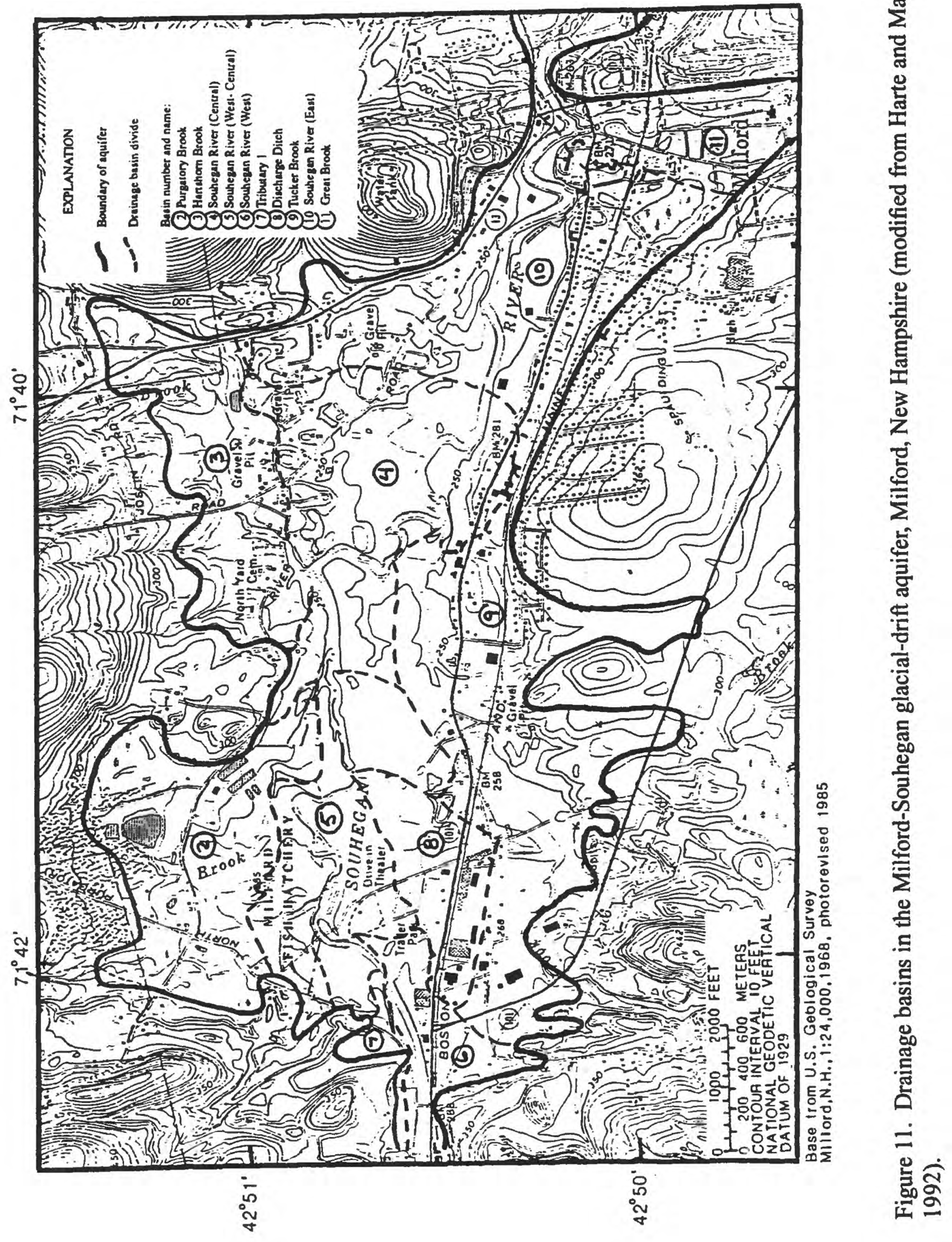


Table 4. Differences between measured and model-calculated stream-seepage gains and losses for dralnage basins in the Milford-Souhegan aquifer, previous and refined model, Milford, New Hampshire

[All streamflow values are in cubic foot per second; fig., figure; --, no data. Negative values indicate stream-seepage loss to the aquifer; positive values denote stream-seepage gain. A negative value indicates either simulated-seepage losses are greater than measured-seepage losses or simulated-seepage gains are less than measured-seepage gains. A positive value indicates either simulated-seepage losses are less than measured-seepage losses or simulated-seepage gains are greater than measured-seepage gains.]

\begin{tabular}{|c|c|c|c|c|c|}
\hline \multirow{2}{*}{$\begin{array}{c}\text { Drainage } \\
\text { basin } \\
\text { (fig. 11) }\end{array}$} & \multirow{2}{*}{$\begin{array}{l}\text { Measured } \\
\text { stream- } \\
\text { flow, } \\
\text { October } \\
1988\end{array}$} & \multicolumn{2}{|c|}{$\begin{array}{l}\text { Model-calculated } \\
\text { streamflow }\end{array}$} & \multicolumn{2}{|c|}{$\begin{array}{l}\text { Difference between measured } \\
\text { and model-calculated streamflow }\end{array}$} \\
\hline & & $\begin{array}{l}\text { Previous } \\
\text { model }\end{array}$ & $\begin{array}{l}\text { Refined } \\
\text { model }\end{array}$ & $\begin{array}{l}\text { Previous } \\
\text { model }\end{array}$ & $\begin{array}{l}\text { Refined } \\
\text { model }\end{array}$ \\
\hline 2 & -0.18 & -0.67 & -0.90 & -0.49 & -0.72 \\
\hline 3 & .05 & .13 & .21 & .08 & .16 \\
\hline 4 & 1.58 & 1.28 & ${ }^{1} 1.25$ & -.30 & -.33 \\
\hline 5 & -.27 & -.50 & .17 & -.77 & -.44 \\
\hline 6 & -.73 & -.87 & -.94 & -.14 & -.21 \\
\hline 7 & -.06 & 0 & -.03 & .06 & .09 \\
\hline 8 & -.31 & -.35 & -.39 & -.04 & -.08 \\
\hline 9 & -.47 & -.34 & -.37 & .13 & .10 \\
\hline 10 & 3.47 & 1.05 & 1.04 & -2.42 & -2.43 \\
\hline 11 & - & -.24 & .24 & -- & -- \\
\hline
\end{tabular}

1. Seepage estimated as 60 percent of sepage in basin 4, June 1988.

the stream to the aquifer.) Stream seepage calculated in the refined model for drainage basin 9 (table 4, fig. 11), in which Tucker Brook is located, was $-0.37 \mathrm{ft}^{3} / \mathrm{s}$. This stream seepage is greater than the $-0.34 \mathrm{ft}^{3} / \mathrm{s}$ calculated in the previous model and indicates a small increase in model-calculated induced stream seepage to the aquifer from this basin.

\section{SUMMARY}

Hydrogeologic data collected since 1990 were used to refine previous estimates of saturated thickness and horizontal hydraulic conductivity of the MilfordSouhegan glacial-drift aquifer, underlying Milford, New Hampshire. Most new data (since 1990) correlated with previous data; however, differences in saturated thickness were found in the northwestern and central parts of the aquifer.

Stream seepage was measured in October 1990 at 45 sites on the main stem of the Souhegan River and on small tributary streams. These measurements indicated that ground-water-seepage patterns in October 1990 were different from those determined in October 1988; differences resulted from the incorporation of additional measurement sites on the Souhegan River and small tributary streams, which improved the delineation of gaining and losing reaches, and the different hydrologic conditions during the October 1990 measurements.

Several refinements were made to the model: (1) small changes were made in the saturated thickness of the aquifer in the northwestern and central parts of the model area to improve the accuracy of aquifer representation in these areas, (2) a solution algorithm was used that allowed cells that had gone dry during the modelsolution process in the previous model to resaturate in the refined model, the new solution algorithm improved the accuracy of solutions of the finite-difference equations for cells at and near modeled withdrawal wells that went dry during the solution process, (3) a preconditioned conjugate-gradient solver was used to solve the numerically complex finite-difference equations for hydraulic head, (4) small changes to horizontal hydrau- 

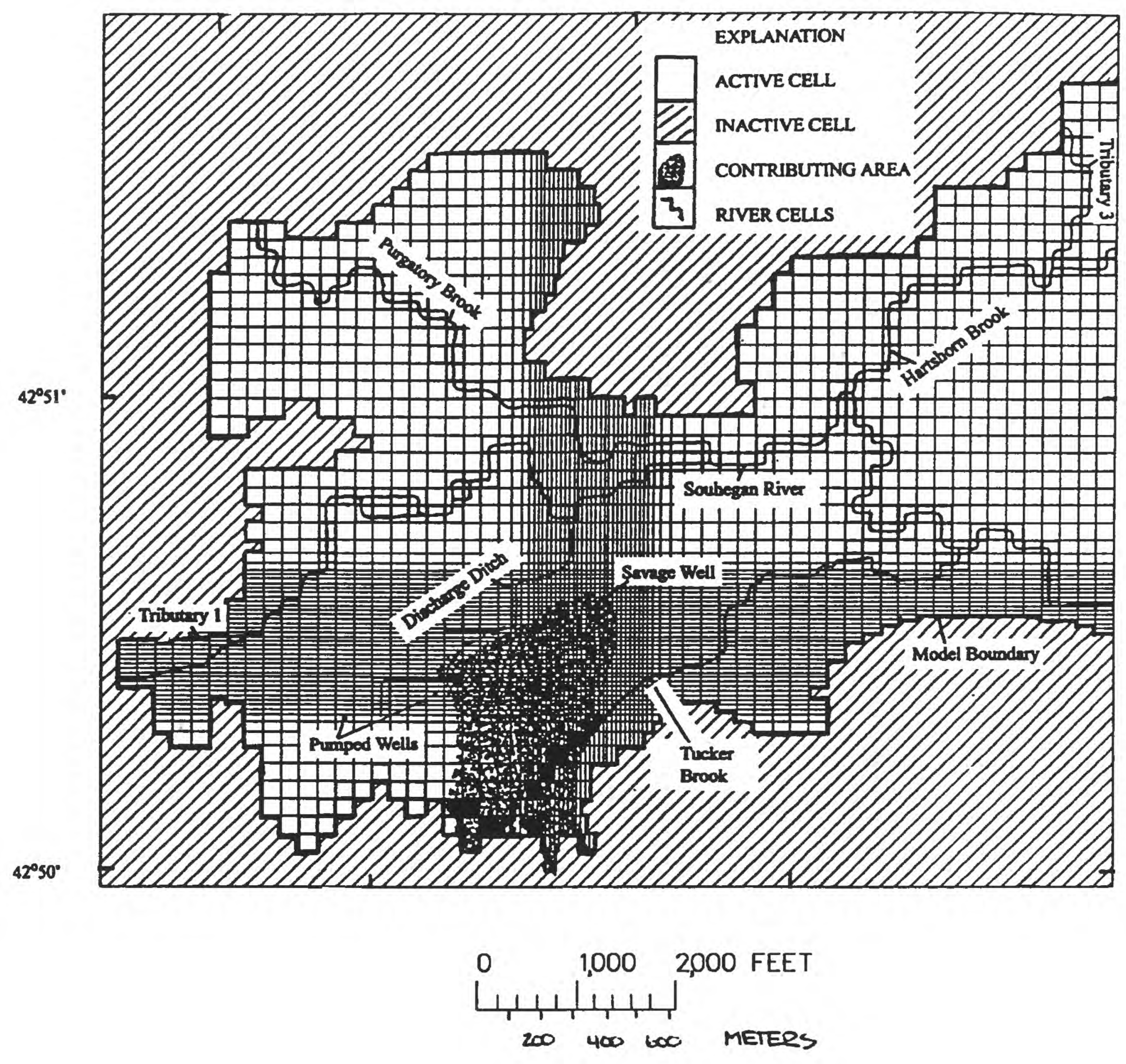

Figure 12. Contributing area to the Savage Well in the refined model of the Milford-Souhegan glacial-drift aquifer, Milford, New Hampshire. 
lic conductivity in the model of the Milford-Souhegan aquifer resulted in small changes in the model-calcuated heads. These changes decreased the difference between model-calculated and measured heads at 22 wells. Estimates of hydraulic conductivity used in the refined model were greater than in the previous model for layers 2 and 3 of the five-layer model.

Stream seepage calculated in the refined model correlated with stream seepage calculated in the previous model. Calculated stream seepage gain and loss patterns in drainage basins 2-9 were similar in the previous and refined model. Stream seepage calculated in the refined model correlated more closely with measured stream seepages than the stream seepage calculated in the previous model in two drainage basins.

The contributing area to the Savage well calculated in the refined model decreased. Under average withdrawal conditions of October 1988, the contributing area decreased by $0.021 \mathrm{mi}^{2}$. The decrease in the contributing area is the result of an increase in model-calculated stream seepage from the discharge ditch and Tucker Brook.

Model-calculated stream seepage in drainage basin 8 , in which the discharge ditch is located, increased from $-0.35 \mathrm{ft}^{3} / \mathrm{s}$ in the previous model to $-0.39 \mathrm{ft}^{3} / \mathrm{s}$ in the refined model. Model-calculated stream seepage in drainage basin 9, near Tucker Brook, increased from $-0.34 \mathrm{ft}^{3} / \mathrm{s}$ in the previous model to $-0.37 \mathrm{ft}^{3} / \mathrm{s}$ in the refined model.

\section{REFERENCES CITED}

Harte, P.T., and Mack, T.J., 1992, Geohydrology of, and simulation of ground-water flow in the Milford-Souhegan glacial-drift aquifer, Milford, New Hampshire: U.S. Geological Survey Water-Resources Investigations Report 91-4177, 90 p.

Hill, M.C., 1990, Preconditioned Conjugate-Gradient 2 (PCG2), A computer program for solving ground-water-flow equations: U.S. Geological Survey Water-Resources Investigations Report 90-4048, 43 p.

HMM Associates, Inc., 1989, Draft remedial investigation, Savage well site, Milford, New Hampshire: Concord, Mass., no. $2176 / \mathrm{HAZ} / 2880,218$ p.

1991, Remedial investigation, Savage well site, Milford, New Hampshire: Concord, Mass., no. 2176-150/HAZ/4814, 1,800 p.
McDonald, M.G., and Harbaugh, A.W., 1988, A modular three-dimensional finite-difference ground-water-flow model: U.S. Geological Survey Techniques of WaterResources Investigations, book 6, chap. A1, 586 p.

McDonald, M.G., Harbaugh, A.W., Orr, B.R., and Ackerman, D.J., 1991, A method of converting no-flow cells to variable-head cells for the U.S. Geological Survey modular finite-difference ground-water-flow model: U.S. Geological Survey Open File Report 91-536, 99 p.

Trecott, P.C., Pinder, G.F., and Larsen, S.P., 1976, Finite-difference model for aquifer simulation in two dimensions with results of numerical experiments: U.S. Geological Survey Techniques of Water-Resources Investigations, book 7, chap. C1, $116 \mathrm{p}$. 


\section{APPENDIX 1. Water levels measured at selected wells in the Milford-Souhegan glacial-drift aquifer, Milford, New Hampshire, 1988 and 1990}


Table 1. Water levels measured at selected wells in the Mllford-Souhegan glaclal-drift aqulfer, Mllford, New Hampshire, 1988 and 1990

(fig., figure; ff, foot; -; no data)

\begin{tabular}{|c|c|c|c|}
\hline $\begin{array}{l}\text { Well No. } \\
\text { (fig 4) }\end{array}$ & $\begin{array}{c}\text { Altitude of water level, } \\
\text { October } 1988 \\
\text { (ft above sea level) }\end{array}$ & $\begin{array}{c}\text { Altitude of water level, } \\
\text { October } 1990 \\
\text { (ft above sea level) }\end{array}$ & $\begin{array}{c}\text { Change in altitude of water } \\
\text { levels from October } 1988 \\
\text { to October } 1990 \\
\text { (ft) }\end{array}$ \\
\hline $\begin{array}{l}1 \\
2 \\
3 \\
4 \\
6\end{array}$ & $\begin{array}{l}237.26 \\
235.79 \\
235.59 \\
235.61 \\
238.13\end{array}$ & $\begin{array}{l}237.44 \\
236.28 \\
236.05 \\
236.01 \\
238.10\end{array}$ & $\begin{array}{l}0.18 \\
.49 \\
.46 \\
.40 \\
-.13\end{array}$ \\
\hline $\begin{array}{l}7 \\
8 \\
16 \\
17 \\
21\end{array}$ & $\begin{array}{l}237.30 \\
237.13 \\
248.81 \\
248.83 \\
250.16\end{array}$ & $\begin{array}{c}239.11 \\
237.88 \\
-- \\
\overline{-} \\
251.07\end{array}$ & $\begin{array}{l}1.81 \\
.75 \\
\overline{-} \\
. \overline{91}\end{array}$ \\
\hline $\begin{array}{l}24 \\
25 \\
30 \\
31 \\
32\end{array}$ & $\begin{array}{l}247.56 \\
243.59 \\
264.43 \\
263.95 \\
264.47\end{array}$ & $\begin{array}{c}249.40 \\
247.18 \\
- \\
- \\
-\end{array}$ & $\begin{array}{l}1.84 \\
3.59 \\
-- \\
-- \\
--\end{array}$ \\
\hline $\begin{array}{l}35 \\
37 \\
38 \\
40 \\
41\end{array}$ & $\begin{array}{l}259.93 \\
260.39 \\
259.86 \\
259.73 \\
259.84\end{array}$ & $\begin{array}{l}- \\
- \\
- \\
- \\
-\end{array}$ & $\begin{array}{l}- \\
- \\
- \\
-\end{array}$ \\
\hline $\begin{array}{l}42 \\
43 \\
44 \\
45 \\
46\end{array}$ & $\begin{array}{l}259.98 \\
260.56 \\
256.85 \\
256.22 \\
259.16\end{array}$ & $\begin{array}{l}26 \overline{-} .18 \\
257.82 \\
258.11 \\
259.94\end{array}$ & $\begin{array}{l}-.62 \\
.97 \\
1.89 \\
.78\end{array}$ \\
\hline $\begin{array}{l}47 \\
48 \\
50 \\
54 \\
55\end{array}$ & $\begin{array}{l}264.11 \\
262.55 \\
253.80 \\
253.55\end{array}$ & $\begin{array}{c}258.96 \\
-- \\
- \\
- \\
-\end{array}$ & $\begin{array}{l}-- \\
-- \\
-- \\
-\end{array}$ \\
\hline $\begin{array}{l}56 \\
72 \\
84 \\
85 \\
86\end{array}$ & $\begin{array}{c}252.99 \\
254.34 \\
235.20 \\
-- \\
--\end{array}$ & $\begin{array}{c}-- \\
242.48 \\
249.55 \\
247.37\end{array}$ & $\begin{array}{c}-- \\
7.28 \\
-- \\
--\end{array}$ \\
\hline $\begin{array}{l}87 \\
88 \\
89 \\
90 \\
91\end{array}$ & $\begin{array}{c}241.65 \\
-- \\
-- \\
-- \\
-\end{array}$ & $\begin{array}{l}245.58 \\
262.54 \\
246.06 \\
247.35 \\
245.90\end{array}$ & $\begin{array}{l}- \\
-- \\
-- \\
-\end{array}$ \\
\hline $\begin{array}{l}92 \\
93 \\
94\end{array}$ & -- & $\begin{array}{l}247.33 \\
245.79 \\
247.72\end{array}$ & $\begin{array}{l}-- \\
-- \\
-\end{array}$ \\
\hline
\end{tabular}


Table 1. Water levels measured at selected wells in the Mllford-Souhegan glaclal-drift aqulfer, Milford, New Hampshire, 1988 and 1990--Continued

\begin{tabular}{|c|c|c|c|}
\hline $\begin{array}{l}\text { Well No. } \\
\text { (fig 4) }\end{array}$ & $\begin{array}{c}\text { Altitude of water level, } \\
\text { October } 1988 \\
\text { (ft above sea level) }\end{array}$ & $\begin{array}{c}\text { Altitude of water level, } \\
\text { October } 1990 \\
\text { (ft above sea level) }\end{array}$ & $\begin{array}{c}\text { Change in altitude of water } \\
\text { levels from October } 1988 \\
\text { to October } 1990 \\
\text { (ft) }\end{array}$ \\
\hline $\begin{array}{l}123 \\
124\end{array}$ & $\begin{array}{l}251.24 \\
252.26\end{array}$ & -- & -- \\
\hline $\begin{array}{l}125 \\
126 \\
132 \\
133 \\
134\end{array}$ & $\begin{array}{l}251.60 \\
235.66 \\
235.65 \\
235.72 \\
235.97\end{array}$ & $\begin{array}{l}- \\
- \\
- \\
-\end{array}$ & $\begin{array}{l}- \\
- \\
- \\
- \\
--\end{array}$ \\
\hline $\begin{array}{l}136 \\
142 \\
143 \\
144 \\
146\end{array}$ & $\begin{array}{l}235.90 \\
235.52 \\
235.58 \\
235.69\end{array}$ & $\begin{array}{l}235.87 \\
236.19 \\
235.98 \\
236.12 \\
--\end{array}$ & $\begin{array}{l}-. \\
0.29 \\
.46 \\
.54 \\
-\end{array}$ \\
\hline $\begin{array}{l}147 \\
150 \\
151 \\
152 \\
164\end{array}$ & $\begin{array}{l}236.01 \\
238.15 \\
237.34 \\
238.74 \\
--\end{array}$ & $\begin{array}{l}238.93 \\
238.24 \\
239.14 \\
257.10\end{array}$ & $\begin{array}{l}-.- \\
.78 \\
.90 \\
.40 \\
--\end{array}$ \\
\hline $\begin{array}{l}165 \\
171 \\
204 \\
208 \\
210\end{array}$ & $\begin{array}{c}25 \overline{9.99} \\
\overline{-} \\
224.60 \\
--\end{array}$ & $\begin{array}{l}256.62 \\
260.74 \\
236.22 \\
240.76 \\
240.76\end{array}$ & $\begin{array}{l}-\overline{.75} \\
.- \\
-- \\
--\end{array}$ \\
\hline $\begin{array}{l}212 \\
213 \\
215 \\
216 \\
218\end{array}$ & $\begin{array}{l}- \\
- \\
- \\
- \\
--\end{array}$ & $\begin{array}{l}260.83 \\
258.07 \\
258.31 \\
257.50 \\
257.30\end{array}$ & $\begin{array}{l}-- \\
- \\
- \\
-\end{array}$ \\
\hline $\begin{array}{l}219 \\
220 \\
221 \\
225 \\
226\end{array}$ & $\begin{array}{l}-- \\
- \\
- \\
- \\
-\end{array}$ & $\begin{array}{l}255.46 \\
253.46 \\
254.60 \\
264.49 \\
266.72\end{array}$ & $\begin{array}{l}- \\
- \\
- \\
- \\
-\end{array}$ \\
\hline $\begin{array}{l}228 \\
231 \\
233 \\
234 \\
250\end{array}$ & $\begin{array}{l}- \\
- \\
-- \\
--\end{array}$ & $\begin{array}{l}261.09 \\
258.17 \\
258.48 \\
267.14 \\
252.57\end{array}$ & $\begin{array}{l}-- \\
-- \\
-- \\
--\end{array}$ \\
\hline $\begin{array}{l}251 \\
254 \\
258 \\
262 \\
264\end{array}$ & $\begin{array}{c}-- \\
257.85 \\
-- \\
--\end{array}$ & $\begin{array}{c}251.12 \\
251.59 \\
-\overline{-} \\
256.31 \\
254.98\end{array}$ & $\begin{array}{l}-- \\
-- \\
-- \\
-- \\
-\end{array}$ \\
\hline
\end{tabular}


Table 1. Water levels measured at selected wells in the Milford-Souhegan glacial-drift aqulfer, Mllford, New Hampshire, 1988 and 1990--Continued

\begin{tabular}{|c|c|c|c|}
\hline $\begin{array}{l}\text { Well No. } \\
\text { (fig 4) }\end{array}$ & $\begin{array}{c}\text { Altitude of water level, } \\
\text { October } 1988 \\
\text { (ft above sea level) }\end{array}$ & $\begin{array}{c}\text { Altitude of water level, } \\
\text { October } 1990 \\
\text { (ft above sea level) }\end{array}$ & $\begin{array}{l}\text { Change in altitude of water } \\
\text { levels from October } 1988 \\
\text { to October } 1990 \\
\text { (ft) }\end{array}$ \\
\hline $\begin{array}{l}267 \\
268\end{array}$ & -- & $\begin{array}{l}250.19 \\
249.01\end{array}$ & -- \\
\hline $\begin{array}{l}271 \\
273 \\
274\end{array}$ & $\begin{array}{l}-- \\
--\end{array}$ & $\begin{array}{l}247.43 \\
250.26 \\
248.59\end{array}$ & $\begin{array}{l}-- \\
- \\
-\end{array}$ \\
\hline $\begin{array}{l}275 \\
276 \\
279 \\
281 \\
282\end{array}$ & $\begin{array}{l}-- \\
-- \\
- \\
- \\
-\end{array}$ & $\begin{array}{l}248.08 \\
247.21 \\
245.40 \\
243.64 \\
244.39\end{array}$ & $\begin{array}{l}-- \\
-- \\
-- \\
-\end{array}$ \\
\hline $\begin{array}{l}283 \\
284 \\
287 \\
293 \\
294\end{array}$ & $\begin{array}{l}- \\
- \\
- \\
-\end{array}$ & $\begin{array}{l}244.56 \\
256.63 \\
255.65 \\
243.40 \\
243.45\end{array}$ & $\begin{array}{l}-- \\
-- \\
-- \\
--\end{array}$ \\
\hline $\begin{array}{l}295 \\
307 \\
308 \\
309 \\
310\end{array}$ & $\begin{array}{l}-- \\
- \\
- \\
- \\
--\end{array}$ & $\begin{array}{l}242.34 \\
272.27 \\
254.48 \\
272.33 \\
260.30\end{array}$ & $\begin{array}{l}-- \\
-- \\
- \\
-\end{array}$ \\
\hline $\begin{array}{l}311 \\
312 \\
313 \\
314 \\
315\end{array}$ & $\begin{array}{l}-- \\
- \\
-- \\
- \\
-\end{array}$ & $\begin{array}{l}259.60 \\
260.65 \\
258.17 \\
258.28 \\
257.52\end{array}$ & $\begin{array}{l}-- \\
-- \\
-- \\
-\end{array}$ \\
\hline $\begin{array}{l}316 \\
317 \\
318 \\
319 \\
320\end{array}$ & $\begin{array}{l}-- \\
- \\
- \\
- \\
-\end{array}$ & $\begin{array}{l}257.42 \\
257.45 \\
256.04 \\
255.88 \\
253.76\end{array}$ & $\begin{array}{l}-- \\
-- \\
-- \\
-\end{array}$ \\
\hline $\begin{array}{l}321 \\
322 \\
323 \\
324\end{array}$ & $\begin{array}{l}-- \\
-- \\
-- \\
-\end{array}$ & $\begin{array}{l}258.57 \\
257.98 \\
257.78 \\
258.04\end{array}$ & $\begin{array}{l}-- \\
-- \\
--\end{array}$ \\
\hline $\begin{array}{l}326 \\
327 \\
328 \\
336 \\
341\end{array}$ & $\begin{array}{l}-- \\
- \\
-- \\
- \\
-\end{array}$ & $\begin{array}{l}256.09 \\
255.97 \\
255.10 \\
261.42 \\
248.50\end{array}$ & $\begin{array}{l}- \\
- \\
-- \\
-\end{array}$ \\
\hline
\end{tabular}


APPENDIX 2. Stream seepage at measurement sites in the Milford-Souhegan glacial-drift aquifer, Milford, New Hampshire, 1988 and 1990 
Table 1. Stream seepage at measurement sites in the Milford-Souhegan glaclal-drift aqulfer, Milford. New Hampshire, 1988 and 1990

(Locations of measurement sites shown in figure $3 ; \mathrm{tt}^{3} / \mathrm{s}$, cublc foot per second;,-- no data)

\begin{tabular}{|c|c|c|c|c|c|c|c|}
\hline \multirow{2}{*}{$\begin{array}{l}\text { Measure- } \\
\text { ment } \\
\text { site No. }\end{array}$} & \multirow[b]{2}{*}{ Stream } & \multirow{2}{*}{$\begin{array}{c}\text { Tributary } \\
\text { to }\end{array}$} & \multicolumn{5}{|c|}{ Stream seepage, in $\mathrm{ft}^{3} / \mathrm{s}$, on given measurement date } \\
\hline & & & $6 / 14 / 88$ & $10 / 14 / 88$ & $10 / 18 / 90$ & $10 / 21 / 90$ & $10 / 22 / 90$ \\
\hline 1 & $\begin{array}{l}\text { Souhegan } \\
\text { River }\end{array}$ & - & 59.1 & 24.1 & 134.0 & -- & 111.2 \\
\hline 2 & $\begin{array}{l}\text { Souhegan } \\
\text { River }\end{array}$ & - & - & 0 & .2 & -- & .2 \\
\hline 3 & $\begin{array}{l}\text { Great } \\
\text { Brook }\end{array}$ & $\begin{array}{l}\text { Souhegan } \\
\text { River }\end{array}$ & 6.2 & 2.3 & 6.7 & -- & - \\
\hline 4 & $\begin{array}{l}\text { Souhegan } \\
\text { River }\end{array}$ & - & 0 & -- & 0 & -- & -- \\
\hline 5 & $\begin{array}{l}\text { Tributary } \\
6\end{array}$ & $\begin{array}{l}\text { Souhegan } \\
\text { River }\end{array}$ & 0 & 0 & - & -- & -- \\
\hline 6 & $\begin{array}{l}\text { Souhegan } \\
\text { River }\end{array}$ & - & 47.0 & 18.7 & - & -- & 124.3 \\
\hline 7 & $\begin{array}{l}\text { Tucker } \\
\text { Brook }\end{array}$ & $\begin{array}{l}\text { Souhegan } \\
\text { River }\end{array}$ & 0 & 0 & -- & 0 & -- \\
\hline 8 & $\begin{array}{c}\text { East } \\
\text { Branch }\end{array}$ & $\begin{array}{l}\text { Hartshorn } \\
\text { Brook }\end{array}$ & .2 & 0 & -- & -- & .3 \\
\hline 9 & $\begin{array}{l}\text { Tributary } \\
5\end{array}$ & $\begin{array}{l}\text { Hartshorn } \\
\text { Brook }\end{array}$ & 0 & 0 & -- & -- & 0 \\
\hline 10 & $\begin{array}{l}\text { West } \\
\text { Branch }\end{array}$ & $\begin{array}{l}\text { Hartshorn } \\
\text { Brook }\end{array}$ & .4 & .6 & - & -- & 1.4 \\
\hline 11 & $\begin{array}{l}\text { Tributary } \\
4\end{array}$ & $\begin{array}{l}\text { Hartshorn } \\
\text { Brook }\end{array}$ & 0 & 0 & -- & - & 0 \\
\hline 12 & $\begin{array}{l}\text { Tributary } \\
3\end{array}$ & $\begin{array}{l}\text { Hartshorn } \\
\text { Brook }\end{array}$ & 0 & 0 & -- & -- & 0 \\
\hline 13 & $\begin{array}{l}\text { Hartshorn } \\
\text { Brook }\end{array}$ & $\begin{array}{l}\text { Souhegan } \\
\text { River }\end{array}$ & .5 & .7 & -- & -- & 2.4 \\
\hline 14 & $\begin{array}{l}\text { Tucker } \\
\text { Brook }\end{array}$ & $\begin{array}{l}\text { Souhegan } \\
\text { River }\end{array}$ & 0 & 0 & -- & - & 0 \\
\hline 15 & $\begin{array}{l}\text { Purgatory } \\
\text { Brook }\end{array}$ & $\begin{array}{l}\text { Souhegan } \\
\text { River }\end{array}$ & 5.2 & 5.8 & -- & -- & 11.7 \\
\hline 16 & $\begin{array}{l}\text { Souhegan } \\
\text { River }\end{array}$ & - & 37.3 & 14.9 & -- & -- & - \\
\hline 17 & $\begin{array}{l}\text { Discharge } \\
\text { Ditch }\end{array}$ & $\begin{array}{l}\text { Souhegan } \\
\text { River }\end{array}$ & .4 & .5 & -- & .4 & -- \\
\hline
\end{tabular}


Table 1. Stream seepage at measurement sltes in the Mllford-Souhegan glaclal-drift aqulfer, Milford, New Hampshire, 1988 and 1990-ContInued

\begin{tabular}{|c|c|c|c|c|c|c|c|}
\hline \multirow{2}{*}{$\begin{array}{l}\text { Measure- } \\
\text { ment } \\
\text { site No. }\end{array}$} & \multirow[b]{2}{*}{ Stream } & \multirow{2}{*}{$\begin{array}{c}\text { Tributary } \\
\text { to }\end{array}$} & \multicolumn{5}{|c|}{ Stream seepage, in $\mathrm{ft}^{3} / \mathrm{s}$, on given measurement date } \\
\hline & & & $6 / 14 / 88$ & $10 / 14 / 88$ & $10 / 18 / 90$ & $10 / 21 / 90$ & $10 / 22 / 90$ \\
\hline 18 & $\begin{array}{l}\text { Discharge } \\
\text { Ditch }\end{array}$ & $\begin{array}{l}\text { Souhegan } \\
\text { River }\end{array}$ & .5 & .8 & -- & .4 & - \\
\hline 19 & $\begin{array}{l}\text { Tucker } \\
\text { Brook }\end{array}$ & $\begin{array}{l}\text { Souhegan } \\
\text { River }\end{array}$ & .6 & .5 & - & 1.2 & - \\
\hline 21 & $\begin{array}{l}\text { Tributary } \\
2\end{array}$ & $\begin{array}{l}\text { Souhegan } \\
\text { River }\end{array}$ & -- & 0 & -- & -- & 0 \\
\hline 22 & $\begin{array}{l}\text { Souhegan } \\
\text { River }\end{array}$ & -- & 35.3 & 14.1 & -- & -- & -- \\
\hline 23 & $\begin{array}{l}\text { Purgatory } \\
\text { Brook }\end{array}$ & $\begin{array}{l}\text { Souhegan } \\
\text { River }\end{array}$ & 2.3 & 1.2 & -- & 6.2 & -- \\
\hline 24 & $\begin{array}{l}\text { Unnamed } \\
\text { Drainage }\end{array}$ & $\begin{array}{l}\text { Souhegan } \\
\text { River }\end{array}$ & 0 & 0 & -- & -- & - \\
\hline 25 & $\begin{array}{l}\text { Purgatory } \\
\text { Brook }\end{array}$ & $\begin{array}{l}\text { Souhegan } \\
\text { River }\end{array}$ & -- & 1.4 & -- & -- & 6.4 \\
\hline 26 & $\begin{array}{l}\text { Tributary } \\
2\end{array}$ & $\begin{array}{l}\text { Souhegan } \\
\text { River }\end{array}$ & -- & .1 & - & -- & .1 \\
\hline 27 & $\begin{array}{l}\text { Tributary } \\
2\end{array}$ & $\begin{array}{l}\text { Souhegan } \\
\text { River }\end{array}$ & 0 & 0 & - & -- & .2 \\
\hline 28 & $\begin{array}{l}\text { Tributary } \\
1\end{array}$ & $\begin{array}{l}\text { Souhegan } \\
\text { River }\end{array}$ & - & -- & - & -- & .1 \\
\hline 29 & $\begin{array}{l}\text { Tributary } \\
1\end{array}$ & $\begin{array}{l}\text { Souhegan } \\
\text { River }\end{array}$ & 0 & 0 & - & -- & .3 \\
\hline 30 & $\begin{array}{l}\text { Tributary } \\
1\end{array}$ & $\begin{array}{l}\text { Souhegan } \\
\text { River }\end{array}$ & .1 & 0 & - & -- & .2 \\
\hline 31 & $\begin{array}{l}\text { Souhegan } \\
\text { River }\end{array}$ & - & 39.1 & 14.1 & 55.4 & -- & 46.7 \\
\hline 32 & $\begin{array}{l}\text { Souhegan } \\
\text { River }\end{array}$ & - & 32.6 & -- & - & -- & - \\
\hline 33 & $\begin{array}{l}\text { Souhegan } \\
\text { River }\end{array}$ & -- & - & -- & -- & -- & ${ }^{1} 24.7$ \\
\hline 34 & $\begin{array}{l}\text { Unnamed } \\
\text { Drainage }\end{array}$ & $\begin{array}{l}\text { Souhegan } \\
\text { River }\end{array}$ & 0 & 0 & -. & -- & 0 \\
\hline 35 & $\begin{array}{l}\text { Purgatory } \\
\text { Brook }\end{array}$ & $\begin{array}{l}\text { Souhegan } \\
\text { River }\end{array}$ & -- & - & ${ }^{1} 8.6$ & ${ }^{1} 8.5$ & ${ }^{1} 8.7$ \\
\hline 37 & $\begin{array}{l}\text { Tributary } \\
6\end{array}$ & $\begin{array}{l}\text { Souhegan } \\
\text { River }\end{array}$ & $\cdots$ & - & -- & -- & ${ }^{1} 3.2$ \\
\hline
\end{tabular}


Table 1. Stream seepage at measurement sites in the Milford-Souhegan glaclal-drift aquifer, Mllford. New Hampshire, 1988 and 1990--Continued

\begin{tabular}{|c|c|c|c|c|c|c|c|}
\hline \multirow{2}{*}{$\begin{array}{l}\text { Measure- } \\
\text { ment } \\
\text { site No. }\end{array}$} & \multirow[b]{2}{*}{ Stream } & \multirow{2}{*}{$\begin{array}{c}\text { Tributary } \\
\text { to }\end{array}$} & \multicolumn{5}{|c|}{ Stream seepage, in $\mathrm{ft}^{3} / \mathrm{s}$, on given measurement date } \\
\hline & & & $6 / 14 / 88$ & $10 / 14 / 88$ & $10 / 18 / 90$ & $10 / 21 / 90$ & $10 / 22 / 90$ \\
\hline 38 & $\begin{array}{l}\text { Souhegan } \\
\text { River }\end{array}$ & - & -- & -- & - & -- & 74.8 \\
\hline 39 & $\begin{array}{l}\text { Souhegan } \\
\text { River }\end{array}$ & - & - & -- & -- & -- & 122.7 \\
\hline 40 & $\begin{array}{l}\text { Souhegan } \\
\text { River }\end{array}$ & -- & -- & - &.- & -- & 122.4 \\
\hline 41 & $\begin{array}{l}\text { Souhegan } \\
\text { River }\end{array}$ & -- & -- & -- & -- & 103 & - \\
\hline 42 & $\begin{array}{l}\text { Souhegan } \\
\text { River }\end{array}$ & -- & -- & -- & -- & - & 113.2 \\
\hline 43 & $\begin{array}{l}\text { Discharge } \\
\text { Ditch }\end{array}$ & $\begin{array}{l}\text { Souhegan } \\
\text { River }\end{array}$ & - & -- & ${ }^{1} .3$ & ${ }^{1} .1$ & ${ }^{1} .2$ \\
\hline 44 & $\begin{array}{l}\text { Discharge } \\
\text { Ditch }\end{array}$ & $\begin{array}{l}\text { Souhegan } \\
\text { River }\end{array}$ & -- & - & ${ }^{1} .6$ & - & - \\
\hline 45 & $\begin{array}{l}\text { Unnamed } \\
\text { Drainage }\end{array}$ & $\begin{array}{l}\text { Souhegan } \\
\text { River }\end{array}$ & -- & -- & ${ }^{1} 1.9$ & - & - \\
\hline
\end{tabular}

${ }^{1}$ Gage-height measurements only. 
APPENDIX 3. Data for selected wells and borings in the Milford-Souhegan aquifer, Milford,

New Hampshire, 1990 
Table 1. Data for selected wells and borings in the Milford-Sounegan aqulfer, Mllford. New Hampshire, 1990

(No., number; fig., figure; ft, foot; -, no data)

\begin{tabular}{|c|c|c|c|c|c|c|c|c|}
\hline \multirow[b]{2}{*}{$\begin{array}{c}\text { Map No. } \\
\text { (fig. 4) }\end{array}$} & \multirow[b]{2}{*}{$\begin{array}{l}\text { Local } \\
\text { identifier }\end{array}$} & \multirow{2}{*}{$\begin{array}{l}\text { Altitude } \\
\text { of land- } \\
\text { surface } \\
\text { (feet } \\
\text { above sea } \\
\text { level) }\end{array}$} & \multirow{2}{*}{$\begin{array}{l}\text { Base of } \\
\text { stratified } \\
\text { drift } \\
\text { (feet } \\
\text { below } \\
\text { land } \\
\text { surface) }\end{array}$} & \multirow[b]{2}{*}{$\begin{array}{l}\text { Depth to } \\
\text { bedrock } \\
\text { (ft) }\end{array}$} & \multirow[b]{2}{*}{$\begin{array}{c}\text { Depth } \\
\text { drilled } \\
\text { (ft) }\end{array}$} & \multicolumn{2}{|c|}{ Depth of screen } & \multirow[b]{2}{*}{$\begin{array}{l}\text { Saturatec } \\
\text { thicknes: } \\
\text { (ft) }\end{array}$} \\
\hline & & & & & & $\begin{array}{l}\text { Top } \\
\text { (ft) }\end{array}$ & $\begin{array}{l}\text { Bottom } \\
\text { (ft) }\end{array}$ & \\
\hline 1 & Keyes 1 & 248.7 & 78.0 & 85.0 & 85.0 & 53.0 & 55.0 & 72.9 \\
\hline 2 & Keyes 2D & 246.6 & -- & -- & 57.0 & 54.5 & 56.5 & -- \\
\hline 3 & Keyes 3D & 244.8 & - & -- & 55.0 & 48.7 & 50.7 & -- \\
\hline 4 & Keyes 4D & 243.3 & -- & $\cdots$ & 53.0 & 49.9 & 51.9 & - \\
\hline 5 & LW-01D & 264.8 & 85.0 & 114.0 & 124.3 & 100.0 & 110.0 & 91.2 \\
\hline 6 & LW-02D & 243.1 & 62.0 & 62.0 & 73.5 & 45.0 & 55.0 & 56.6 \\
\hline 7 & LW-03D & 247.3 & 80.0 & 80.0 & 90.2 & 44.5 & 54.5 & 69.7 \\
\hline 8 & LW-04D & 243.4 & 80.0 & 80.0 & 90.0 & 40.0 & 50.0 & 73.4 \\
\hline 9 & MOW-33 & 260.0 & - & - & 52.0 & -- & $\ldots$ & -- \\
\hline 10 & GW-02D & 255.4 & 34.0 & 34.0 & 44.0 & 19.0 & 19.0 & -- \\
\hline 11 & GW-03D & 252.4 & 23.0 & 23.0 & 38.0 & 28.0 & 38.0 & - \\
\hline 12 & GW-04D & 255.6 & 19.0 & 19.0 & 31.5 & 21.5 & 31.5 & -- \\
\hline 13 & GW-05D & 261.0 & 33.0 & 33.0 & 48.0 & 23.0 & 33.0 & 22.0 \\
\hline 14 & RFW-1 & 256.0 & 28.0 & 28.0 & 28.0 & 8.0 & 28.0 & 26.3 \\
\hline 15 & RFW-2 & 254.2 & 35.0 & 35.0 & 35.0 & 10.0 & 35.0 & 30.9 \\
\hline 16 & RFW-3 & 254.5 & 43.0 & 43.0 & 43.0 & 13.0 & 43.0 & 38.1 \\
\hline 17 & RFW-4 & 252.1 & 16.0 & 16.0 & 16.0 & 6.0 & 16.0 & 13.6 \\
\hline 18 & PA-1 & 258.3 & -- & -- & 11.5 & - & 8.7 & -- \\
\hline 19 & PA-2 & 255.5 & - & - & 11.0 & - & 8.7 & - \\
\hline 20 & PA-3 & 259.1 & - & -- & 11.5 & - & 7.8 & -- \\
\hline 21 & MI-7 & 255.4 & - & -- & - & - & -- & -- \\
\hline 22 & MI-8 & 261.9 & - & -- & - & - & - & -- \\
\hline 23 & MI-10 & 252.1 & 59.0 & 59.0 & 59.0 & 44.0 & 47.0 & 54.3 \\
\hline 24 & MI-11 & 252.9 & 63.0 & 63.0 & 63.0 & 40.0 & 56.0 & 57.1 \\
\hline 25 & MI-12 & 251.6 & 50.0 & 50.0 & 50.3 & 43.0 & 49.0 & 43.7 \\
\hline 26 & MI-15 & 266.5 & -- & -. & -- & - & - & -- \\
\hline 27 & MI-16 & 269.1 &.- & -- & -- & - & - & - \\
\hline 29 & MOW-36 & 260.0 & -- & - & 14.6 & -- & -- & -- \\
\hline 30 & MI-19 & 275.6 & 25.0 & 62.0 & 82.5 & 65.0 & 80.0 & 51.2 \\
\hline 31 & MI-20 & 275.6 & -- & -- & 82.5 & 10.0 & 40.0 & -- \\
\hline
\end{tabular}


Table 1. Data for selected wells and borings in the Milford-Souhegan aquifer. Mliford, New Hampshire, 1990-Contlnued

\begin{tabular}{|c|c|c|c|c|c|c|c|c|}
\hline \multirow[b]{2}{*}{$\begin{array}{c}\text { Map No. } \\
\text { (fig. 4) }\end{array}$} & \multirow[b]{2}{*}{$\begin{array}{l}\text { Local } \\
\text { identifier }\end{array}$} & \multirow{2}{*}{$\begin{array}{l}\text { Altitude } \\
\text { of land- } \\
\text { surface } \\
\text { (feet } \\
\text { above sea } \\
\text { level) }\end{array}$} & \multirow{2}{*}{$\begin{array}{l}\text { Base of } \\
\text { stratified } \\
\text { drift } \\
\text { (feet } \\
\text { below } \\
\text { land } \\
\text { surface) }\end{array}$} & \multirow[b]{2}{*}{$\begin{array}{l}\text { Depth to } \\
\text { bedrock } \\
\text { (ft) }\end{array}$} & \multirow[b]{2}{*}{$\begin{array}{l}\text { Depth } \\
\text { drifled } \\
\text { (ft) }\end{array}$} & \multicolumn{2}{|c|}{ Depth of screen } & \multirow[b]{2}{*}{$\begin{array}{l}\text { Saturated } \\
\text { thickness } \\
\text { (ft) }\end{array}$} \\
\hline & & & & & & $\begin{array}{l}\text { Top } \\
\text { (ft) }\end{array}$ & $\begin{array}{l}\text { Bottom } \\
\text { (ft) }\end{array}$ & \\
\hline 32 & MI-20A & 274.7 & - & -- & 14.8 & - & -- & -- \\
\hline 33 & $\mathrm{MI}-21$ & 273.0 & 30.0 & -- & 53.0 & 15.0 & 40.0 & -- \\
\hline 34 & MI-21A & 270.0 & - & -- & -- & -- & -- & -- \\
\hline 35 & MI-22 & 270.0 & 75.0 & 94.0 & 112.5 & 99.0 & 114.0 & 84.2 \\
\hline 36 & MI-22A & 270.1 & -- & - & 11.7 & - & - & - \\
\hline 37 & MI-23 & 270.0 & 75.0 & 94.0 & 112.5 & 10.0 & 75.0 & 84.9 \\
\hline 38 & MI-24 & 270.6 & 77.0 & 96.0 & 101.5 & 10.0 & 85.0 & 85.8 \\
\hline 39 & MI-24A & 271.7 & -- & - & 14.0 & - & - & -- \\
\hline 40 & MI-25 & 270.6 & 57.0 & 104.0 & 110.0 & 101.8 & 111.0 & 93.7 \\
\hline 41 & MI-26 & 270.6 & 57.0 & 104.0 & 110.0 & 8.0 & 88.0 & 93.7 \\
\hline 42 & MI-27 & 270.7 & 57.0 & 86.0 & 92.0 & 13.0 & 78.0 & 75.5 \\
\hline 43 & MI-28 & 270.3 & 38.0 & 56.0 & 56.0 & 35.0 & 55.0 & 46.2 \\
\hline 44 & MI-30 & 265.4 & 70.0 & -- & 75.0 & 27.0 & 72.0 & -- \\
\hline 44 & MI-30 & 265.4 & 70.0 & - & 75.0 & 27.0 & 72.0 & - \\
\hline 45 & MI-31 & 266.0 & - & -- & 60.0 & 36.0 & 54.0 & - \\
\hline 46 & MI-32 & 270.2 & - & -- & 95.0 & 30.0 & 75.0 & -- \\
\hline 47 & MI-33 & 268.2 & $\cdots$ & - & -. & - & -- & - \\
\hline 49 & MI-35 & 265.9 & - & - & -- & - & - & -- \\
\hline 50 & MI-36 & 270.0 & - & -- & - & - & -- & - \\
\hline 51 & MI-37 & 270.6 & - & -- & - & - & - & - \\
\hline 52 & MI-38 & 270.0 & -- & -- & -- & - & -- & -- \\
\hline 54 & MI-41 & 258.6 & -- & -- & 20.0 & - & -- & - \\
\hline 55 & MI-42 & 257.4 & - & -- & 20.0 & - & -- & -- \\
\hline 56 & MI-43 & 257.2 & -- & -- & 20.0 & - & -- & -- \\
\hline 57 & MOW-63 & 270.0 & 65.0 & 65.0 & 69.0 & 53.0 & 62.0 & 53.6 \\
\hline 58 & MI-44 & 259.8 & - & - & 20.0 & - & - & -- \\
\hline 59 & MI-45 & 264.9 & - & -- & -- & - & - & -- \\
\hline 60 & MI-46 & 267.3 & -- & -- & -- & - & - & -- \\
\hline 61 & MI-47 & 270.0 & -- & - & - & - & -- & - \\
\hline 62 & MI-48 & 260.3 & - & -- & - & - & -- & -- \\
\hline
\end{tabular}


Table 1. Data for selected wells and borings in the Mllford-Souhegan aqulfer, Mllford, New Hampshire, 1990-Continued

\begin{tabular}{|c|c|c|c|c|c|c|c|c|}
\hline \multirow[b]{2}{*}{$\begin{array}{c}\text { Map No. } \\
\text { (fig. 4) }\end{array}$} & \multirow[b]{2}{*}{$\begin{array}{l}\text { Local } \\
\text { identifier }\end{array}$} & \multirow{2}{*}{$\begin{array}{c}\text { Altitude } \\
\text { of land- } \\
\text { surface } \\
\text { (feet } \\
\text { above sea } \\
\text { level) }\end{array}$} & \multirow{2}{*}{$\begin{array}{l}\text { Base of } \\
\text { stratified } \\
\text { drift } \\
\text { (feet } \\
\text { below } \\
\text { land } \\
\text { surface) }\end{array}$} & \multirow[b]{2}{*}{$\begin{array}{l}\text { Depth to } \\
\text { bedrock } \\
\text { (ft) }\end{array}$} & \multirow[b]{2}{*}{$\begin{array}{l}\text { Depth } \\
\text { drilled } \\
\text { (ft) }\end{array}$} & \multicolumn{2}{|c|}{ Depth of screen } & \multirow[b]{2}{*}{$\begin{array}{c}\text { Saturated } \\
\text { thickness } \\
\text { (ft) }\end{array}$} \\
\hline & & & & & & $\begin{array}{l}\text { Top } \\
\text { (ft) }\end{array}$ & $\begin{array}{l}\text { Bottom } \\
\text { (ft) }\end{array}$ & \\
\hline 64 & -- & 265.3 & -- & - & - & - & -- & -- \\
\hline 65 & -- & 260.0 & -- & - & - & - & -- & - \\
\hline 66 & -- & 270.0 & -- & -- & - & - & -. & -- \\
\hline 67 & -- & 250.0 & -- & -- & -- & - & -- & -- \\
\hline 68 & - & 267.9 & -- & -- & -- & -- & -. & -- \\
\hline 69 & -- & 266.3 & - & - & - & -- & -- & -- \\
\hline 70 & $\cdots$ & 264.1 & - & - & - & - & -- & - \\
\hline 71 & $-=$ & 264.0 & -- & - & -- & - & -- & -- \\
\hline 72 & MI-62 & 260.0 & 58.0 & 60.7 & 60.7 & 17.0 & 58.0 & 55.0 \\
\hline 73 & MI-64 & 259.9 & - & - & -- & -- & -- & -- \\
\hline 74 & MOW-35 & 260.0 & 59.0 & 59.0 & 60.0 & - & -- & 56.0 \\
\hline 75 & MOA-1 & 239.5 & 74.0 & 74.0 & 74.0 & - & -- & 64.2 \\
\hline 76 & MOA-2 & 244.6 & - & -- & 13.0 & -- & -- & -- \\
\hline 77 & MOA-3 & 241.1 & 52.0 & 52.0 & 52.0 & -- & -- & 46.3 \\
\hline 78 & MOA-4 & 249.5 & 43.0 & 54.0 & 54.0 & 33.0 & 38.0 & 46.5 \\
\hline 84 & FH-1 & 268.0 & - & -- & 66.0 & 51.0 & 66.0 & -- \\
\hline 85 & FH-2 & 262.4 & - & -- & - & -- & -- & -- \\
\hline 86 & FH-3 & 260.0 & - & -- & - & 33.0 & 43.0 & -- \\
\hline 87 & FH-4 & 262.2 & - & -- & - & -- & - & -- \\
\hline 88 & FH85-1 & 261.0 & - &.- & 26.0 & - & -- & -- \\
\hline 89 & FH85-2 & 250.0 & - & -- & 41.0 & 34.0 & 39.0 & -- \\
\hline 90 & FH85-3 & 252.8 & -- & -- & 31.0 & 24.0 & 29.0 & - \\
\hline 91 & FH85-4 & 251.6 & - & -- & 31.0 & 24.0 & 29.0 & -- \\
\hline 92 & FH85-5 & 252.3 & -- & -. & 31.0 & 24.0 & 29.0 & -- \\
\hline 93 & FH85-6 & 252.0 & - & -- & 26.0 & 22.0 & 25.0 & -- \\
\hline 94 & FH85-7 & 253.5 & - & -- & 31.0 & 21.0 & 26.0 & -. \\
\hline 95 & FH85-8A & 260.0 & - & -- & 26.0 & 20.0 & 26.0 & -- \\
\hline 96 & FH 1974 & 254.5 & -- & - & -- & -- & -- & -- \\
\hline 97 & $\mathrm{Bl}$ & 269.9 & 31.0 & -- & 43.0 & - & - & - \\
\hline 98 & B3 & 269.3 & 34.0 & -- & 34.0 & -- & -- & - \\
\hline
\end{tabular}


Table 1. Data for selected wells and borings in the Mliford-Souhegan aquifer, Milford, New Hampshlre, 1990-Continued

\begin{tabular}{|c|c|c|c|c|c|c|c|c|}
\hline \multirow[b]{2}{*}{$\begin{array}{l}\text { Map No. } \\
\text { (fig. 4) }\end{array}$} & \multirow[b]{2}{*}{$\begin{array}{l}\text { Local } \\
\text { identifier }\end{array}$} & \multirow{2}{*}{$\begin{array}{l}\text { Altitude } \\
\text { of land- } \\
\text { surface } \\
\text { (feet } \\
\text { above sea } \\
\text { level) }\end{array}$} & \multirow{2}{*}{$\begin{array}{l}\text { Base of } \\
\text { stratified } \\
\text { drift } \\
\text { (feet } \\
\text { below } \\
\text { land } \\
\text { surface) }\end{array}$} & \multirow[b]{2}{*}{$\begin{array}{l}\text { Depth to } \\
\text { bedrock } \\
\text { (ft) }\end{array}$} & \multirow[b]{2}{*}{$\begin{array}{l}\text { Depth } \\
\text { drilled } \\
\text { (ft) }\end{array}$} & \multicolumn{2}{|c|}{ Depth of screen } & \multirow[b]{2}{*}{$\begin{array}{c}\text { Saturated } \\
\text { thickness } \\
\text { (ft) }\end{array}$} \\
\hline & & & & & & $\begin{array}{l}\text { Top } \\
\text { (ft) }\end{array}$ & $\begin{array}{c}\text { Bottom } \\
\text { (ft) }\end{array}$ & \\
\hline 99 & B4 & 270.0 & 39.0 & - & 54.5 & - & - & -- \\
\hline 100 & B6 & 269.0 & 26.2 & 26.2 & 26.2 & - & - & 24.8 \\
\hline 101 & B8 & 269.7 & -- & -- & 26.0 & -- & -- & -- \\
\hline 102 & B9 & 275.3 & 36.0 & - & 40.3 & - & -- & -- \\
\hline 103 & B11 & 275.0 & 37.0 & - & 38.0 & -- & -- & $-\infty$ \\
\hline 104 & B12 & 275.4 & 42.0 & -- & 48.4 & - & -- & -- \\
\hline 122 & WW-125 & 269.0 & -- & - & - & -- & -- & -- \\
\hline 123 & GW-01S & 256.1 & -- & -- & 20.0 & 6.0 & 16.0 & -- \\
\hline 124 & GW-01D & 256.5 & 40.0 & 56.0 & 76.4 & 60.0 & 70.0 & 51.2 \\
\hline 125 & GW-01M & 256.7 & 40.0 & -- & 41.0 & 30.0 & 40.0 & -- \\
\hline 126 & Keyes & 240.1 & -- & -- & 60.0 & 50.0 & 60.0 & $\cdots$ \\
\hline 127 & Haywood & 256.3 & -- & -- & -- & -- & - & -- \\
\hline 128 & Savage & 261.0 & -- & -- & 52.0 & 42.0 & 52.0 & -- \\
\hline 129 & Keyes-1 & 241.7 & 50.0 & 50.0 & 50.0 & 41.0 & 50.0 & 41.5 \\
\hline 130 & Keyes-2 & 240.5 & 65.0 & 65.0 & 65.0 & 52.0 & 60.0 & 55.9 \\
\hline 131 & Keyes-3 & 240.3 & 52.0 & 52.0 & 52.0 & 42.0 & 50.0 & 45.4 \\
\hline 132 & Potter-1D & 251.8 & 67.0 & 80.0 & 80.0 & 55.0 & 57.0 & 63.3 \\
\hline 133 & Potter-2D & 253.8 & $\cdots$ & -- & 60.0 & 56.0 & 58.0 & -- \\
\hline 134.0 & Potter-3D & 253.7 & - & - & 60.0 & 56.0 & 58.0 & -- \\
\hline 135 & Ford-34 & 241.4 & 50.0 & 50.0 & 50.0 & 40.0 & 50.0 & 40.0 \\
\hline 136 & Ford-Obs & 247.1 & 46.0 & 46.0 & 46.0 & - & -- & 33.0 \\
\hline 137 & Ford-33 & 240.0 & 40.0 & 40.0 & 40.0 & -- & -- & 27.0 \\
\hline 138 & Ford-32 & 240.0 & 42.0 & 42.0 & 42.0 & 32.0 & 42.0 & 29.0 \\
\hline 139 & Ford-1 & 239.8 & 47.0 & 50.0 & 50.0 & 35.0 & 50.0 & 37.3 \\
\hline 140 & Ford-5 & 241.7 & 35.0 & 35.0 & 35.0 & - & - & 23.2 \\
\hline 141 & Ford-4 & 245.3 & 47.0 & 47.0 & 47.0 & -- & - & 34.7 \\
\hline 142 & Keyes-2S & 246.1 & -- & -- & 57.0 & 18.0 & 20.0 & -- \\
\hline 143 & Keyes-3S & 246.0 & -- & - & 55.0 & 16.6 & 18.6 & -- \\
\hline 144 & Keyes-4S & 244.3 & -- & -- & 53.0 & 14.4 & 16.4 & -- \\
\hline 145 & Potter-1S & 252.0 & 67.0 & 80.0 & 80.0 & 16.0 & 18.0 & 63.1 \\
\hline
\end{tabular}


Tabie 1. Data for selected wells and borings in the Milford-Souhegan aquifer, Milford, New Hampshire, 1990-Continued

\begin{tabular}{|c|c|c|c|c|c|c|c|c|}
\hline \multirow[b]{2}{*}{$\begin{array}{c}\text { Map No. } \\
\text { (fig. 4) }\end{array}$} & \multirow[b]{2}{*}{$\begin{array}{l}\text { Local } \\
\text { identifier }\end{array}$} & \multirow{2}{*}{$\begin{array}{l}\text { Altitude } \\
\text { of land- } \\
\text { surface } \\
\text { (feet } \\
\text { above sea } \\
\text { level) }\end{array}$} & \multirow{2}{*}{$\begin{array}{l}\text { Base of } \\
\text { stratified } \\
\text { drift } \\
\text { (feet } \\
\text { below } \\
\text { land } \\
\text { surface) }\end{array}$} & \multirow[b]{2}{*}{$\begin{array}{l}\text { Depth to } \\
\text { bedrock } \\
\text { (ft) }\end{array}$} & \multirow[b]{2}{*}{$\begin{array}{l}\text { Depth } \\
\text { drilled } \\
\text { (ft) }\end{array}$} & \multicolumn{2}{|c|}{ Depth of screen } & \multirow[b]{2}{*}{$\begin{array}{l}\text { Saturated } \\
\text { thickness } \\
\text { (ft) }\end{array}$} \\
\hline & & & & & & $\begin{array}{l}\text { Top } \\
\text { (ft) }\end{array}$ & $\begin{array}{c}\text { Bottom } \\
\text { (ft) }\end{array}$ & \\
\hline 146 & Potter-2S & 253.7 & -- & - & 60.0 & 18.0 & 20.0 & -- \\
\hline 147 & Potter-3S & 253.7 & -- & -- & 60.0 & 17.0 & 19.0 & -- \\
\hline 148 & LW-01M & 265.1 & - & - & 60.0 & 42.6 & 52.6 & -- \\
\hline 149 & LW-01S & 265.2 & -- & - & 40.0 & 25.6 & 35.6 & -- \\
\hline 150 & LW-02S & 243.4 & - & - & 17.0 & 4.0 & 14.0 & -- \\
\hline 151 & LW-03S & 250.0 & - & - & 25.0 & 9.0 & 19.0 & -- \\
\hline 152 & LW-04S & 244.8 & - & -- & 20.0 & 5.0 & 15.0 & -- \\
\hline 153 & MOW-38 & 262.7 & -- & -- & 16.0 & - & - & -- \\
\hline 154 & MOW-32 & 261.8 & - & -- & 54.5 & -- & -- & -- \\
\hline 155 & GW-02S & 255.2 & -- & -- & 17.0 & 6.0 & 16.0 & - \\
\hline 156 & GW-03S & 252.4 & -- & -- & 20.0 & 8.4 & 18.4 & -- \\
\hline 157 & GW-04S & 255.6 & -- & -- & 15.4 & 5.4 & 15.4 & - \\
\hline 158 & GW-05S & 264.2 & -- & -- & 19.0 & 7.0 & 17.0 & - \\
\hline 160 & Hamp-B1 & 266.3 & -- & -- & 21.5 & 10.0 & 20.0 & -- \\
\hline 162 & Hamp-B3 & 258.9 & -- & -- & 30.0 & 20.0 & 30.0 & -- \\
\hline 163 & MI-2 & 258.9 & -- & -- & 49.0 & 37.0 & 47.0 & -- \\
\hline 164 & MI-3 & 260.0 & -- & -- & 49.0 & 44.0 & 49.0 & -- \\
\hline 165 & MI-4 & 259.6 & - & -- & 49.0 & 39.0 & 49.0 & -- \\
\hline 166 & MI-5 & 260.0 & - & -- & 49.0 & 39.0 & 49.0 & -- \\
\hline 167 & MI-6 & 259.2 & -- & - & -- & -- & -- & - \\
\hline 168 & MI-6A & 259.5 & -- & -- & -- & - & -- & -- \\
\hline 169 & MI-9 & 262.2 & -- & -- & -- & - & -- & -- \\
\hline 170 & MI-14 & 260.0 & - & -- & -- & - & -- & -- \\
\hline 171 & MI-29 & 269.9 & 49.0 & 51.5 & 51.5 & 31.5 & 51.5 & 40.7 \\
\hline 172 & MI-40 & 259.8 & - & - & 17.0 & - & -- & -- \\
\hline 173 & H12-71 & 250.0 & 28.0 & 36.0 & 36.0 & -- & -- & 31.1 \\
\hline 174 & H11-71 & 241.6 & 35.0 & 39.0 & 39.0 & 25.0 & 35.0 & 33.7 \\
\hline 175 & H9-71 & 250.8 & 25.0 & 28.5 & 28.5 & 20.0 & 25.0 & 21.6 \\
\hline 176 & H8-71 & 250.0 & 25.0 & 32.0 & 32.0 & 20.0 & 25.0 & 24.7 \\
\hline 177 & H6-71 & 249.5 & 11.0 & 16.0 & 16.0 & - & -- & -- \\
\hline 178 & H7-71 & 246.9 & 12.0 & 15.0 & 15.0 & -- & -- & -- \\
\hline
\end{tabular}


Table 1. Data for selected wells and borings in the Milford-Souhegan aquifer, Mllford, New Hampshire, 1990-Continued

\begin{tabular}{|c|c|c|c|c|c|c|c|c|}
\hline \multirow[b]{2}{*}{$\begin{array}{l}\text { Map No. } \\
\text { (fig. 4) }\end{array}$} & \multirow[b]{2}{*}{$\begin{array}{l}\text { Local } \\
\text { identifier }\end{array}$} & \multirow{2}{*}{$\begin{array}{l}\text { Altitude } \\
\text { of land- } \\
\text { surface } \\
\text { (feet } \\
\text { above sea } \\
\text { level) }\end{array}$} & \multirow{2}{*}{$\begin{array}{l}\text { Base of } \\
\text { stratified } \\
\text { drift } \\
\text { (feet } \\
\text { below } \\
\text { land } \\
\text { surface) }\end{array}$} & \multirow[b]{2}{*}{$\begin{array}{l}\text { Depth to } \\
\text { bedrock } \\
\text { (ft) }\end{array}$} & \multirow[b]{2}{*}{$\begin{array}{l}\text { Depth } \\
\text { drilled } \\
\text { (ft) }\end{array}$} & \multicolumn{2}{|c|}{ Depth of screen } & \multirow[b]{2}{*}{$\begin{array}{l}\text { Saturated } \\
\text { thickness } \\
\text { (ft) }\end{array}$} \\
\hline & & & & & & $\begin{array}{l}\text { Top } \\
\text { (ft) }\end{array}$ & $\begin{array}{l}\text { Bottom } \\
\text { (ft) }\end{array}$ & \\
\hline 179 & $\mathrm{H} 10-71$ & 250.9 & 28.0 & 34.0 & 34.0 & 18.0 & 28.0 & 26.0 \\
\hline 180 & H5-71 & 250.5 & 28.0 & 31.0 & 31.0 & 23.0 & 28.0 & 22.3 \\
\hline 183 & B-61 & 239.9 & 23.0 & 23.0 & 23.0 & - & - & -- \\
\hline 188 & MOA-25 & 262.0 & 60.0 & 72.0 & 72.0 & 50.0 & 60.0 & 61.9 \\
\hline 189 & MOA-35 & 265.2 & 12.0 & 12.0 & 12.0 & -- & -- & -- \\
\hline 190 & MOA-37 & 260.0 & 13.0 & 13.0 & 13.0 & - & -- & - \\
\hline 191 & MOA-38 & 270.0 & 14.0 & 14.0 & 14.0 & - & -- & -- \\
\hline 193 & MOW-15 & 260.0 & -- & -- & 55.0 & -- & - & - \\
\hline 194 & MOW-58 & 268.7 & 76.0 & 76.0 & 76.0 & 54.0 & 63.0 & 65.7 \\
\hline 195 & MOW-64 & 260.0 & 76.0 & 76.0 & 76.0 & 41.0 & 49.0 & 70.4 \\
\hline 196 & MOW-65 & 260.0 & 73.0 & 73.0 & 73.0 & 54.0 & 62.0 & 67.5 \\
\hline 197 & MOW-66 & 252.8 & 37.0 & 37.0 & 37.0 & 27.0 & 33.0 & 34.3 \\
\hline 198 & MOW-67 & 249.8 & 45.0 & 45.0 & 45.0 & 37.0 & 43.0 & 42.2 \\
\hline 199 & MOW-68 & 245.0 & 53.0 & 53.0 & 53.0 & 36.0 & 42.0 & 49.0 \\
\hline 200 & MOW-25 & 259.7 & 4.0 & 4.0 & 4.0 & -- & - & - \\
\hline 201 & MOW-26 & 260.0 & 14.0 & 14.0 & 14.0 & - & - & -- \\
\hline 202 & MOW-19 & 260.8 & -- & -- & 52.0 & - & -- & - \\
\hline 203 & MI-63 & 270.0 & - & - & 67.0 & 24.0 & 64.0 & -- \\
\hline 204 & MI-13 & 249.6 & 33.0 & -- & 33.0 & 12.0 & 18.0 & -- \\
\hline 205 & HAMP GW 4 & 270.5 & - & -- & - & -- & - & -- \\
\hline 207 & RB-38 & 259.7 & -- & - & 13.0 & -- & -- & - \\
\hline 208 & FH-5 & 267.9 & -- & - & 65.0 & 50.0 & 65.0 & -- \\
\hline 209 & HMM 1C & 275.5 & 62.0 & 62.0 & 71.0 & 51.0 & 61.0 & 51.1 \\
\hline 210 & HMM 2B & 270.0 & 79.0 & 115.0 & 164.0 & 71.0 & 81.0 & 112.1 \\
\hline 212 & HMM 4B & 270.1 & 45.0 & 45.0 & 98.0 & 46.0 & 56.0 & 39.3 \\
\hline 213 & HMM 5B & 269.3 & 62.0 & 62.0 & 69.0 & 49.0 & 59.0 & 51.0 \\
\hline 214 & HMM 6B & 270.0 & 71.0 & 71.0 & 80.0 & 56.0 & 65.0 & 61.1 \\
\hline 215 & HMM 7B & 266.4 & 55.5 & 58.5 & 69.0 & 45.0 & 56.0 & 53.4 \\
\hline 216 & HMM 8B & 265.0 & 67.0 & 90.0 & 94.0 & 57.0 & 67.0 & 83.4 \\
\hline 217 & HMM 9C & 262.2 & 91.0 & 91.0 & 105.0 & 79.0 & 90.0 & 80.6 \\
\hline 218 & HMM 10C & 266.5 & 91.6 & 91.6 & 101.0 & 81.0 & 91.0 & 86.3 \\
\hline
\end{tabular}


Table 1. Data for selected wells and borings in the Mllford-Souhegan aqulfer, Mllford, New Hampshire, 1990-Continued

\begin{tabular}{|c|c|c|c|c|c|c|c|c|}
\hline \multirow[b]{2}{*}{$\begin{array}{c}\text { Map No. } \\
\text { (fig. 4) }\end{array}$} & \multirow[b]{2}{*}{$\begin{array}{l}\text { Local } \\
\text { identifier }\end{array}$} & \multirow{2}{*}{$\begin{array}{l}\text { Altitude } \\
\text { of land- } \\
\text { surface } \\
\text { (feet } \\
\text { above sea } \\
\text { level) }\end{array}$} & \multirow{2}{*}{$\begin{array}{l}\text { Base of } \\
\text { stratified } \\
\text { drift } \\
\text { (feet } \\
\text { below } \\
\text { land } \\
\text { surface) }\end{array}$} & \multirow[b]{2}{*}{$\begin{array}{l}\text { Depth to } \\
\text { bedrock } \\
\text { (ft) }\end{array}$} & \multirow[b]{2}{*}{$\begin{array}{l}\text { Depth } \\
\text { drilled } \\
\text { (ft) }\end{array}$} & \multicolumn{2}{|c|}{ Depth of screen } & \multirow[b]{2}{*}{$\begin{array}{l}\text { Saturated } \\
\text { thickness } \\
\text { (ft) }\end{array}$} \\
\hline & & & & & & $\begin{array}{l}\text { Top } \\
\text { (ft) }\end{array}$ & $\begin{array}{l}\text { Bottom } \\
\text { (ft) }\end{array}$ & \\
\hline 219 & HMM $11 R$ & 261.0 & 59.0 & 65.0 & 115.0 & 52.0 & 64.0 & 59.4 \\
\hline 220 & HMM 12A & 262.4 & 64.0 & 66.0 & 78.0 & 25.0 & 35.0 & 56.4 \\
\hline 221 & HMM 13B & 260.0 & 59.0 & 64.0 & 76.0 & 48.0 & 58.0 & 61.4 \\
\hline 222 & HMM 14R & 253.7 & 60.0 & 60.0 & 110.0 & 50.0 & 60.0 & 57.1 \\
\hline 223 & HMM 15A & 250.8 & 27.5 & 27.5 & 39.0 & 11.0 & 27.0 & 13.2 \\
\hline 225 & MW-26 & 268.49 & 0.0 & -- & -- & 3.0 & 13.0 & 0.0 \\
\hline 226 & MW-25 & 270.67 & 0.0 & -- & -- & 4.0 & 12.0 & 0.0 \\
\hline 228 & MW-3 & 268.84 & 21.5 & - & -- & 11.5 & 21.5 & 13.7 \\
\hline 231 & $M W-18 A$ & 267.55 & 82.0 & - & -- & 44.5 & 54.5 & 72.6 \\
\hline 233 & $M W-16 A$ & 267.33 & 60.0 & - & -- & 16.9 & 26.9 & 51.2 \\
\hline 234 & MW-28 & 276.01 & 0.0 & - & - & 5.0 & 15.0 & 0.0 \\
\hline 235 & MW-27 & 273.76 & 0.0 & -- & - & 5.0 & 15.0 & 0.0 \\
\hline 237 & $M W-23 A$ & 265.38 & 86.0 & - & -- & 20.0 & 30.0 & 0.0 \\
\hline 250 & SP-8 & 257.44 & 0.0 & -- & -- & 0.0 & 0.0 & 0.0 \\
\hline 251 & SP-7 & 258.16 & 0.0 & - & -- & 0.0 & 0.0 & 0.0 \\
\hline 252 & SP-6 & 0.0 & .0 .0 & - & - & 0.0 & 0.0 & 0.0 \\
\hline 254 & SP-5 & 255.28 & 0.0 & - & -- & 0.0 & 0.0 & 0.0 \\
\hline 255 & $M W-24 A$ & 256.01 & 40.5 & - & -- & 19.5 & 29.5 & -- \\
\hline 258 & MW-17A & 264.18 & 99.3 & - & - & 19.8 & 29.8 & 93.0 \\
\hline 262 & MW-29 & 260.40 & - & - & -- & 2.5 & 12.5 & -- \\
\hline 264 & MW-20A & 260.48 & 47.5 & - & -- & 15.0 & 25.0 & 42.0 \\
\hline 267 & SP-4 & 257.13 & - & - & -- & - & -- & -- \\
\hline 268 & SP-3 & 255.30 & -- & - & -- & - & -- & -- \\
\hline 271 & P-15 & 251.68 & -- & -. & - & - & -- & - \\
\hline 273 & HP-1 & 252.26 & -- & -. & -- & -- & $=$ & -- \\
\hline 274 & $\mathrm{HP}-2$ & 251.04 & - & - & - & - & -- & -- \\
\hline 275 & HP-3 & 250.38 & -- & - & - & - & -- & -- \\
\hline 276 & P-10 & 251.76 & - & -- & -- & - & -- & -- \\
\hline 278 & $M W-21 A$ & 259.08 & 63.8 & - & - & 3.8 & 13.8 & - \\
\hline 279 & SP-2 & 249.94 & -- & -- & -- & - & -- & - \\
\hline 280 & P-16 & 258.30 & - & -- & - & - & - & - \\
\hline
\end{tabular}


Table 1. Data for selected wells and borings in the Milford-Souhegan aquifer, Mllford, New Hampshire, 1990-Continued

\begin{tabular}{|c|c|c|c|c|c|c|c|c|}
\hline \multirow[b]{2}{*}{$\begin{array}{c}\text { Map No. } \\
\text { (fig. 4) }\end{array}$} & \multirow[b]{2}{*}{$\begin{array}{c}\text { Local } \\
\text { identifier }\end{array}$} & \multirow{2}{*}{$\begin{array}{l}\text { Altitude } \\
\text { of land- } \\
\text { surface } \\
\text { (feet } \\
\text { above sea } \\
\text { level) }\end{array}$} & \multirow{2}{*}{$\begin{array}{c}\text { Base of } \\
\text { stratified } \\
\text { drift } \\
\text { (feet } \\
\text { below } \\
\text { land } \\
\text { surface) }\end{array}$} & \multirow[b]{2}{*}{$\begin{array}{l}\text { Depth to } \\
\text { bedrock } \\
\text { (ft) }\end{array}$} & \multirow[b]{2}{*}{$\begin{array}{l}\text { Depth } \\
\text { drilled } \\
\text { (ft) }\end{array}$} & \multicolumn{2}{|c|}{ Depth of screen } & \multirow[b]{2}{*}{$\begin{array}{l}\text { Saturated } \\
\text { thickness } \\
\text { (ft) }\end{array}$} \\
\hline & & & & & & $\begin{array}{l}\text { Top } \\
\text { (ft) }\end{array}$ & $\begin{array}{l}\text { Bottom } \\
\text { (ft) }\end{array}$ & \\
\hline 281 & MW-34 & 256.31 & 20.5 & - & - & 9.5 & 19.5 & 7.8 \\
\hline 282 & P-17A & 250.64 & - & -- & - & -- & -- & - \\
\hline 283 & P-17B & 252.64 & - & - & - & - & - & - \\
\hline 284 & Ferguson & 278.28 & - & -- & -- & -- & -- & -- \\
\hline 287 & Gorman & 270.45 & -- & -- & -- & -- & -- & -- \\
\hline 293 & $M W-22 A$ & 250.10 & 47.0 & - & - & 13.8 & 23.8 & 40.3 \\
\hline 294 & MW-22B & 250.10 & 47.0 & -- & -- & 33.5 & 43.5 & 40.4 \\
\hline 295 & P-13 & 248.34 & -- & -- & -- & -- & - & -- \\
\hline 296 & MW-32A & 247.61 & - & -- & - & 7.0 & 17.0 & - \\
\hline 297 & MW-32B & 248.32 & 43.5 & -- & -- & 31.8 & 41.8 & -- \\
\hline 307 & $\mathrm{HM}-1 \mathrm{~A}$ & 279.37 & -- & -- & -- & 5.0 & 17.0 & -- \\
\hline 308 & HMM-13A & 257.78 & 58.0 & -- & -- & -- & -- & 54.8 \\
\hline 309 & MW-1B & 279.70 & 62.0 & -- & -- & 35.4 & 45.4 & -- \\
\hline 310 & $M W-2 A$ & 266.65 & -- & -- & -- & 29.0 & 39.0 & -- \\
\hline 311 & MW-2R & 266.20 & 78.0 & -- & -- & -- & -- & 71.4 \\
\hline 312 & MW-4A & 266.60 & 45.0 & -- & -- & 19.7 & 29.7 & -- \\
\hline 313 & MW-5A & 267.72 & 61.4 & -- & -- & 28.0 & 38.0 & -- \\
\hline 314 & MW-7A & 262.26 & 58.6 & - & -- & 3.2 & 13.2 & 51.9 \\
\hline 315 & MW-8A & 261.95 & 67.0 & -- & - & 4.5 & 16.5 & 54.6 \\
\hline 316 & MW-10A & 262.00 & 91.6 & -- & - & 19.0 & 29.0 & 62.6 \\
\hline 317 & MW-10B & 261.97 & 91.6 & -- & - & 44.0 & 54.0 & 87.0 \\
\hline 318 & MW-11A & 260.99 & 64.0 & -- & -- & 20.5 & 30.5 & 59.1 \\
\hline 319 & MW-11B & 260.96 & - & -- & -- & 52.3 & 62.3 & - \\
\hline 320 & MW-12B & 264.36 & 66.0 & -- & - & 56.0 & 66.0 & -- \\
\hline 321 & MW-16B & 267.43 & 60.0 & -- & - & 39.6 & 49.6 & 51.1 \\
\hline 322 & MW-17B & 264.36 & 99.3 & - & - & 52.4 & 62.4 & 92.9 \\
\hline 323 & MW-17C & 264.45 & 99.3 & $\ldots$ & - & 52.4 & 62.4 & 92.9 \\
\hline 324 & MW-18B & 267.56 & 82.0 & -- & -- & 44.5 & 54.5 & 72.5 \\
\hline 326 & MW-19A & 261.37 & - & -- & -- & 23.5 & 33.5 & - \\
\hline 327 & MW-19B & 260.71 & 35.0 & -- & -- & 39.0 & 49.0 & 30.3 \\
\hline
\end{tabular}


Table 1. Data for selected wells and borings in the Milford-Souhegan aqulfer, Milford, New Hampshire, 1990-Continued

\begin{tabular}{|c|c|c|c|c|c|c|c|c|}
\hline \multirow[b]{2}{*}{$\begin{array}{c}\text { Map No. } \\
\text { (fig. 4) }\end{array}$} & \multirow[b]{2}{*}{$\begin{array}{l}\text { Local } \\
\text { identifier }\end{array}$} & \multirow{2}{*}{$\begin{array}{l}\text { Altitude } \\
\text { of land- } \\
\text { surface } \\
\text { (feet } \\
\text { above sea } \\
\text { level) }\end{array}$} & \multirow{2}{*}{$\begin{array}{l}\text { Base of } \\
\text { stratified } \\
\text { drift } \\
\text { (feet } \\
\text { below } \\
\text { land } \\
\text { surface) }\end{array}$} & \multirow[b]{2}{*}{$\begin{array}{l}\text { Depth to } \\
\text { bedrock } \\
\text { (ft) }\end{array}$} & \multirow[b]{2}{*}{$\begin{array}{l}\text { Depth } \\
\text { drilled } \\
\text { (ft) }\end{array}$} & \multicolumn{2}{|c|}{ Depth of screen } & \multirow[b]{2}{*}{$\begin{array}{l}\text { Saturated } \\
\text { thickness } \\
\text { (ft) }\end{array}$} \\
\hline & & & & & & $\begin{array}{l}\text { Top } \\
\text { (ft) }\end{array}$ & $\begin{array}{l}\text { Bottom } \\
\text { (ft) }\end{array}$ & \\
\hline 328 & MW-20B & 260.37 & 47.5 & -- & -- & 35.0 & 45.0 & 42.2 \\
\hline 329 & $M W-21 B$ & 259.19 & - & - & -- & 20.0 & 30.0 & - \\
\hline 330 & $M W-21 C$ & 259.34 & 63.8 & -- & -- & 44.1 & 54.1 & -- \\
\hline 331 & MW-23B & 265.32 & 63.8 & -- & -- & 48.0 & 58.0 & -- \\
\hline 332 & $M W-23 C$ & 265.26 & 86.0 & -- & - & 48.0 & 58.0 & -- \\
\hline 333 & MW-24B & 255.66 & 40.5 & -- & $-\infty$ & 31.1 & 41.1 & - \\
\hline 334 & MW-34 & 256.31 & 20.5 & -- & -- & - & -- & - \\
\hline 335 & P-1 & 276.60 & -- & -- & - & -- & -- & - \\
\hline 336 & P-2 & 268.62 & -- & - & - & - & - & - \\
\hline 339 & SP-9 & 259.41 & - & - & - & - & -- & - \\
\hline 340 & SP-10 & 262.42 & - & - & -- & -- & -- & -- \\
\hline 341 & $M W-14 B$ & 252.95 & 60.0 & -. & $\cdots$ & 50.0 & 60.0 & 55.5 \\
\hline 342 & MW-15B & 257.05 & 27.5 & - & - & 29.4 & 36.4 & -- \\
\hline
\end{tabular}

